\title{
Association of $\mathrm{Ca}_{\mathrm{V}} 1.3 \mathrm{~L}-\mathrm{Type}$ Calcium Channels with Shank
}

\author{
Hua Zhang, ${ }^{1}$ Anton Maximov, ${ }^{1}$ Yu Fu, ${ }^{1}$ Fang Xu, ${ }^{1}$ Tie-Shan Tang, ${ }^{1}$ Tatiana Tkatch, ${ }^{2}$ D. James Surmeier, ${ }^{2}$ and \\ Ilya Bezprozvanny ${ }^{1}$ \\ ${ }^{1}$ Department of Physiology, University of Texas Southwestern Medical Center at Dallas, Dallas, Texas 75390, and 2Department of Physiology, Feinberg \\ School of Medicine, Northwestern University, Chicago, Illinois 60611
}

\begin{abstract}
Neurons express multiple types of voltage-gated calcium $\left(\mathrm{Ca}^{2+}\right)$ channels. Two subtypes of neuronal L-type $\mathrm{Ca}^{2+}$ channels are encoded by $\mathrm{Ca}_{\mathrm{V}} 1.2$ and $\mathrm{Ca}_{\mathrm{V}} 1.3$ pore-forming subunits. Both $\mathrm{Ca}_{\mathrm{V}} 1.2$ and $\mathrm{Ca}_{\mathrm{V}} 1.3$ subunits contain class I PDZ (postsynaptic density-95/Discs large/zona occludens-1) domain-binding consensus at their $\mathrm{C}$ termini. In yeast two-hybrid screen of rat brain cDNA library with the C-terminal bait of $\mathrm{Ca}_{\mathrm{V}} 1.3 \mathrm{a}$ (long C-terminal splice variant) $\mathrm{L}$-type $\mathrm{Ca}^{2+}$ channel subunit, we isolated multiple clones of postsynaptic adaptor protein Shank. We demonstrated a specific association of $\mathrm{Ca}_{\mathrm{V}} 1.3 \mathrm{a} \mathrm{C}$ termini, but not of $\mathrm{Ca}_{\mathrm{v}} 1.2 \mathrm{C}$ termini, with Shank PDZ domain in vitro. We further demonstrated that the proline-rich region present in $\mathrm{C}$ termini of $\mathrm{Ca}_{\mathrm{v}} 1.3 \mathrm{a}$ subunit binds to Shank Src homology 3 domain. We established that $\mathrm{Ca}_{\mathrm{v}} 1.3 \mathrm{a}$ and Shank localized to postsynaptic locations in cultured rat hippocampal neurons. By expressing epitope-tagged recombinant $\mathrm{Ca}_{\mathrm{V}} 1.3$ subunits in rat hippocampal neuronal cultures, we demonstrated that the presence of Shank-binding motifs in $\mathrm{Ca}_{\mathrm{V}} 1.3 \mathrm{a}$ sequence is both necessary and sufficient for synaptic clustering of $\mathrm{Ca}_{\mathrm{V}} 1.3 \mathrm{~L}$-type $\mathrm{Ca}^{2+}$ channels. In experiments with dominant-negative peptides and dihydropyridine-resistant $\mathrm{Ca}_{\mathrm{v}}$ 1.3a mutants, we demonstrated an importance of Shank-binding motif in $\mathrm{Ca}_{\mathrm{V}}$ 1.3a sequence for phosphorylated cAMP response element-binding protein (pCREB) signaling in cultured hippocampal neurons. Our results directly link $\mathrm{Ca}_{\mathrm{V}} 1.3$ neuronal L-type $\mathrm{Ca}^{2+}$ channels to macromolecular signaling complex formed by Shank and other modular adaptor proteins at postsynaptic density and provide novel information about the role played by $\mathrm{Ca}_{\mathrm{v}} 1.3 \mathrm{~L}-\mathrm{type} \mathrm{Ca}^{2+}$ channels in pCREB signaling.
\end{abstract}

Key words: calcium channels; PDZ domains; protein targeting; postsynaptic density; CREB; synapse; synaptic plasticity

\section{Introduction}

Neurons express a diverse complement of voltage-gated calcium $\left(\mathrm{Ca}^{2+}\right)$ channels (Catterall, 2000). N-type $\left(\mathrm{Ca}_{\mathrm{V}} 2.2\right)$ and P/Qtype $\left(\mathrm{Ca}_{\mathrm{V}} 2.1\right) \mathrm{Ca}^{2+}$ channels mediate rapid $\mathrm{Ca}^{2+}$ influx into the presynaptic terminal that triggers synaptic vesicle fusion and neurotransmitter release (Dunlap et al., 1995). Neuronal L-type $\mathrm{Ca}^{2+}$ channels do not support synaptic transmission; however, recent data indicate that $\mathrm{L}$-type $\mathrm{Ca}^{2+}$ channels play a critical role in neuronal $\mathrm{Ca}^{2+}$ signaling. $\mathrm{Ca}^{2+}$ influx via postsynaptic L-type $\mathrm{Ca}^{2+}$ channels activates phosphorylated cAMP response element-binding protein (pCREB) (Bito et al., 1996; Dolmetsch et al., 2001; Weick et al., 2003) and nuclear factor of activated T-cells c4 (Graef et al., 1999) neuronal nuclear transcription factors. Resulting changes in protein expression may play a role in mediating long-term changes in synaptic strength (Deisseroth et

Received Aug. 9, 2004; revised Dec. 10, 2004; accepted Dec. 14, 2004.

This work was supported by the Robert A. Welch Foundation and National Institutes of Health Grants R01 NS39552 (I.B.), NS34696 (D.J.S.), and DA12958 (D.J.S.). We thank Yin Wang, Masaya Okamoto, and Shuza Sugita for advice with yeast two-hybrid screen; Thomas C. Südhof for the gift of rat brain CDNA library; Eunjoon Kim for anti-Shank antibodies; Susumu Seino, Diana Lipscombe, and Weifeng Xu for the $\mathrm{Ca}_{\mathrm{v}} 1.3$ clones; Morgan Sheng and Carlo Sala for GFP-Shank1B plasmid; Richard W. Tsien for the $\mathrm{Ca}_{\mathrm{v}} 1.2, \beta_{3}$ and $\alpha_{2} \delta$ - 1 clones; Haruhiko Bito and Paul Mermelstein for advice with pCREB experiments; Nan Wang, Xiaohong Shen, Tianhua Lei, and Linda Patterson for expert technical and administrative assistance; and Paul Mermelstein, Eunjoon Kim, and Alexander Petrenko for comments on this manuscript.

Correspondence should be addressed to Dr. llya Bezprozvanny, Department of Physiology, University of Texas Southwestern Medical Center at Dallas, Dallas, Texas 75390. E-mail: Ilya.Bezprozvanny@UTSouthwestern.edu. DOI:10.1523/JNEUROSCI.4554-04.2005

Copyright $\odot 2005$ Society for Neuroscience $\quad 0270-6474 / 05 / 251037-13 \$ 15.00 / 0$ al., 2003). Despite an important role of L-type $\mathrm{Ca}^{2+}$ channels in neuronal $\mathrm{Ca}^{2+}$ signaling, very little is known about molecular and cellular mechanisms involved in L-type $\mathrm{Ca}^{2+}$ channel function in neurons. Neuronal L-type $\mathrm{Ca}^{2+}$ channels are encoded by $\mathrm{Ca}_{\mathrm{V}} 1.2\left(\alpha_{1 \mathrm{C}}\right)$ or $\mathrm{Ca}_{\mathrm{V}} 1.3\left(\alpha_{1 \mathrm{D}}\right)$ pore-forming subunits (Hell et al., 1993; Lipscombe et al., 2004). When compared with channels encoded by $\mathrm{Ca}_{\mathrm{V}} 1.2$ subunit, the channels encoded by $\mathrm{Ca}_{\mathrm{V}} 1.3$ subunit are less sensitive to dihydropyridines and open at more negative membrane potentials (Koschak et al., 2001; Xu and Lipscombe, 2001; Lipscombe et al., 2004; Olson et al., 2005). Genetic ablation of $\mathrm{Ca}_{\mathrm{V}} 1.3$ subunit resulted in congenital deafness and dysfunction of pancreatic $\beta$-cell and cardiac sinoatrial node (Platzer et al., 2000; Namkung et al., 2001; Zhang et al., 2002; Mangoni et al., 2003). The neuronal phenotype of $\mathrm{Ca}_{\mathrm{V}} 1.3$ knockout mice is described by Olson et al. (2005).

The $\mathrm{Ca}_{\mathrm{V}} 1.2\left(\alpha_{1 \mathrm{C}}\right)$ subunit contains a class $1 \mathrm{PDZ}$ [postsynaptic density-95 (PSD-95)/Discs large/zona occludens-1 (ZO-1)] domain binding C-terminal motif VSXL (see Fig. $1 A$ ) that has been shown to associate with PDZ domains of neuronal interleukin-16 (NIL-16) precursor protein (Kurschner and Yuzaki, 1999) and channel-interacting PDZ domain protein (CIPP) (Kurschner et al., 1998). Association with PDZ proteins plays an important role in coupling $\mathrm{Ca}_{\mathrm{V}} 1.2 \mathrm{~L}$-type $\mathrm{Ca}^{2+}$ channels with phosphorylation of nuclear CREB (Weick et al., 2003). The C-terminal region of $\mathrm{Ca}_{\mathrm{V}} 1.3$ subunit is alternatively spliced ( $\mathrm{Safa}$ et al., 2001; $\mathrm{Xu}$ and Lipscombe, 2001). The "long" $\mathrm{Ca}_{\mathrm{V}} 1.3$ a splice variant also contains a class $1 \mathrm{PDZ}$ domain-binding C-terminal 
motif ITTL (see Fig. 1A), but its binding partners are unknown. Here, we performed a yeast two-hybrid ( $\mathrm{Y} 2 \mathrm{H})$ screen of rat brain cDNA library with the $\mathrm{Ca}_{\mathrm{V}} 1.3 \mathrm{a}$ C-terminal bait and isolated multiple clones of Shank postsynaptic PDZcontaining adaptor protein. In biochemical experiments, we confirmed specific association between $\mathrm{Ca}_{V} 1.3 \mathrm{a}$ C-terminal and Shank-PDZ domain and discovered that proline-rich region in $\mathrm{Ca}_{\mathrm{V}} 1.3 \mathrm{a} \mathrm{C}$-terminal region binds to Shank-Src homology 3 (SH3) domain. In experiments with cultured hippocampal neurons, we demonstrated that the presence of Shank-binding motifs in $\mathrm{Ca}_{\mathrm{V}} 1.3 \mathrm{a}$ sequence is both necessary and sufficient for synaptic clustering of $\mathrm{Ca}_{\mathrm{V}} 1.3 \mathrm{~L}$-type $\mathrm{Ca}^{2+}$ channels and that the same motif plays an important role in $\mathrm{Ca}_{\mathrm{V}} 1.3$-mediated signaling to $\mathrm{pCREB}$. Our results directly link $\mathrm{Ca}_{\mathrm{V}} 1.3 \mathrm{~L}$-type $\mathrm{Ca}^{2+}$ channels to the macromolecular signaling complex formed by Shank in postsynaptic spines (Kennedy, 2000).

\section{Materials and Methods}

Plasmid construction. pLexN (bait) and pVp16-3 (prey) vectors were used for $\mathrm{Y} 2 \mathrm{H}$, pGEX-KG (Amersham Biosciences, Piscataway, NJ) for glutathione $S$-transferase (GST) fusion proteins; and pEGFP-C3 (Clontech, Palo Alto, CA) for green fluorescent protein (GFP) fusion proteins. Rat $\mathrm{Ca}_{\mathrm{V}} 1.3 \mathrm{a}\left(\alpha_{1 \mathrm{D}-1}\right)$ (Ihara et al., 1995; Xu and Lipscombe, 2001) constructs were as follows: LDC, 2142-2155; LDC2, 1640-2155; LDC2 $\Delta$ C, 1640-2150; LDC5, 2121-2155; LDC5 $\Delta$ C, 2121-2150. Deletions and mutations of LDC bait were generated by PCR and verified by sequencing. Rabbit $\mathrm{Ca}_{\mathrm{V}} 1.2\left(\alpha_{1 \mathrm{C}}\right)$ (Mikami et al., 1989) construct was as follows: LCC, 2121-2171. Shank constructs were as follows: Shank3-PDZ, 566-671 of rat Shank3a; Shank3-SH3-PDZ, 473-664 of Shank3a; Shank1-PDZ, 659-764 of rat Shank1a; Shank1-SH3, 447-558 of rat Shank1B; Shank1SH3-PDZ, 447-703 of rat Shank1B. The GFPShank1B construct was described previously (Sala et al., 2003). Constructs encoding PDZ domains of PSD-95, PSD-93, synapseassociated protein 102 (SAP-102), ZO-1, and Mint1 were described previously (Maximov et al., 1999). HA-Ca $\mathrm{C}_{\mathrm{V}} 1.3 \mathrm{a}$ construct was generated by replacing NheI [5' untranslated region (UTR)]/BsiWI (518) fragment of $\mathrm{Ca}_{\mathrm{V}} 1.3 \mathrm{a}$ plasmid in pcDNA6/V5-His vector ( $\mathrm{Xu}$ and Lipscombe, 2001 ) with PCR-amplified 450 bp $5^{\prime}$ fragment of HA-Ca $2.2\left(\mathrm{HA}-\alpha_{1 \mathrm{~B}}\right.$ ) expression construct (Maximov and Bezprozvanny, 2002). The HA$\mathrm{Ca}_{\mathrm{V}} 1.3 \mathrm{a}-\Delta \mathrm{C}$ construct (deletion of amino acids ${ }^{2151} \mathrm{CITTL}^{2155}$ ) was generated by PCR and verified by sequencing. The HA-Ca $1.3 \mathrm{~b}$ construct was generated by subcloning BamH1 (2,751)/SacII (3'UTR) fragment from $\mathrm{Ca}_{\mathrm{V}} 1.3 \mathrm{~b}$ plasmid (Xu and Lipscombe, 2001) into HA-Ca 1 1.3a construct. The $\mathrm{Ca}_{\mathrm{V}} 1.3-\mathrm{T} 1033 \mathrm{Y}$ mutation was generated by Quick-Change kit (Stratagene, La Jolla, CA) and verified by sequencing.

Yeast two-hybrid methods. L40 yeast strain was sequentially transformed by lithium acetate method with the pLexN-LDC bait and rat brain cDNA library (kind gift from Thomas Südhof, University of Texas Southwestern, Dallas, TX) in pVp16-3 prey vector. The primary trans-

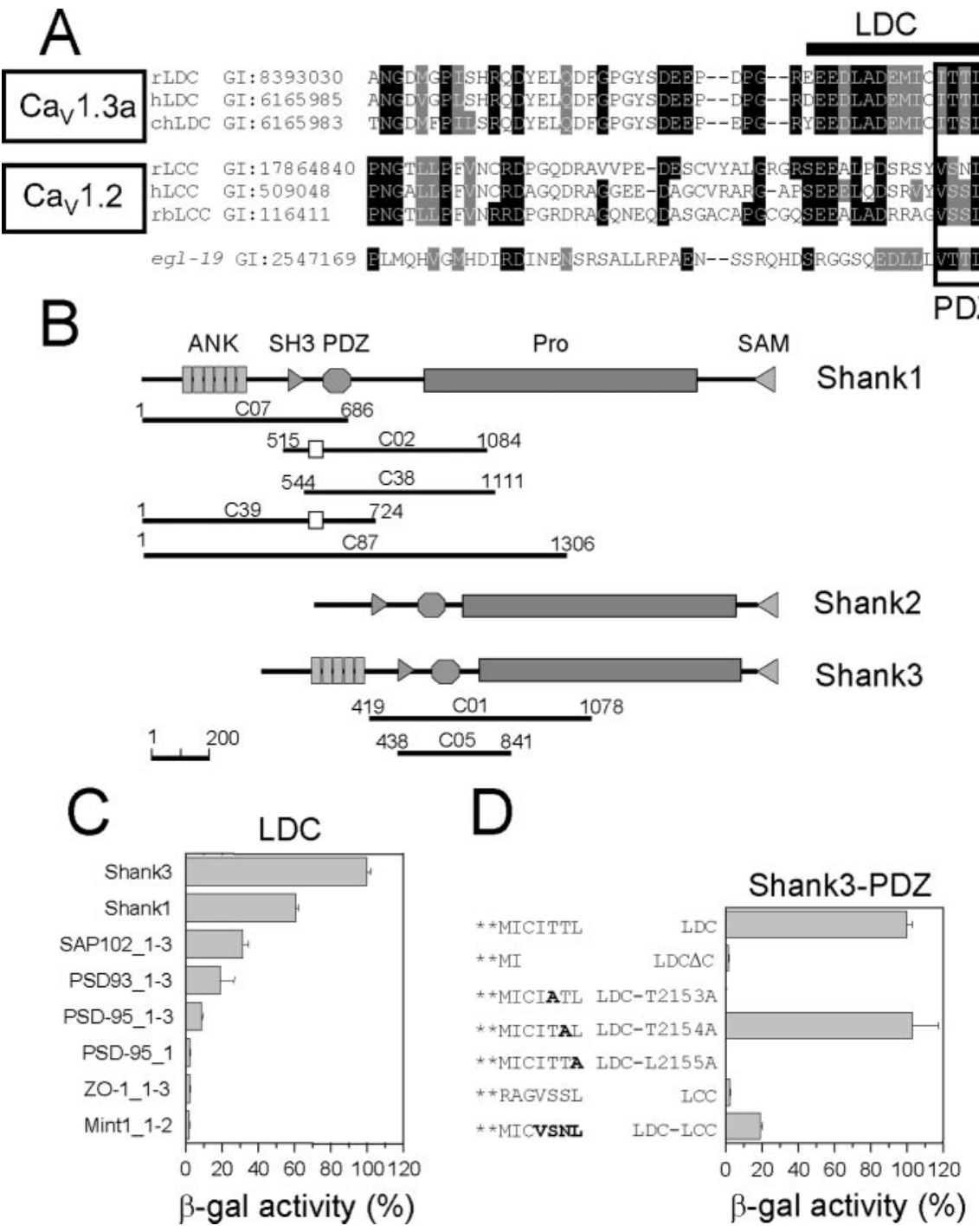

Figure 1. $\quad C a_{v} 1.3 a C$ terminal binds to Shank-PDZ domain in yeast two-hybrid assay. $A$, Sequence alignment of rat $C a_{v} 1.3 a$ C-terminal region (aa 2109-2155) with the corresponding regions of human and chicken $\mathrm{Ca}_{\mathrm{v}} 1$.3a subunits; with rat, human, and rabbit $\mathrm{Ca}_{y} 1.2$ subunits, and with the $C$. elegans $\mathrm{L}$-type $\mathrm{Ca}^{2+}$ channel pore-forming subunit (egl-19). Sequence accession numbers (above). B, Domain structure of rat Shank1 (2087 aa), rat Shank 2 (1474 aa), and rat Shank 3 (1740 aa). The boundaries of isolated PDZ domains of Shank1, Shank3, and other adaptor proteins was measured in $\mathrm{Y} 2 \mathrm{H}$ liquid assay by $\beta$-galactosidase bait, and chimeric LDC-LCC bait were tested for the strength of association with Shank3-PDZ domain in Y2H assay by $\beta$-galactosidase activity. In C and D, the data were normalized to LDC/Shank3-PDZ pair and shown as mean $\pm \operatorname{SEM}(n \geq 3)$.

formation efficiency was $6 \times 10^{6}$. The positive clones were selected on -THUL selection plates and rescued in HB101 Escherichia coli strain. Y2H liquid assays were performed as described previously (Maximov et al., 1999).

In vitro binding assays. GST-fusion proteins were expressed in BL21 E. Coli strain and purified as described previously (Maximov et al., 1999). GFP-tagged proteins were expressed in human embryonic kidney 293 (HEK293) cells by $\mathrm{Ca}^{2+}$-phosphate method and extracted in buffer A containing 0.5\% Triton X-100, 20 mm Imidasole, pH 6.8, $100 \mathrm{~mm} \mathrm{NaCl}$, $5 \mathrm{~mm}$ EDTA, and protease inhibitors. Protein extracts were clarified by centrifugation at $100,000 \times g$ and used in GST pull-down experiments performed as described previously (Maximov et al., 1999).

Hippocampal neuronal cultures and immunocytochemistry. Primary embryonic day 18 (E18) rat hippocampal neuronal cultures were established and analyzed by immunostaining at $10-12 \mathrm{~d}$ in vitro (DIV) as 
described previously (Maximov and Bezprozvanny, 2002). For targeting experiments, primary hippocampal neuronal cultures at 9-10 DIV were transfected with GFP-LDC2/5 plasmids or cotransfected with HA$\mathrm{Ca}_{\mathrm{V}} 1.3 / \beta_{3} / \alpha_{2} \delta$-1 plasmids using calcium phosphate method as described previously (Maximov and Bezprozvanny, 2002). Subcellular localization of GFP-LDC constructs was determined by GFP imaging $72 \mathrm{~h}$ after transfections using confocal microscope (Zeiss LS800; Zeiss, Thornwood, $\mathrm{NY}$ ). Subcellular localization of $\mathrm{HA}-\mathrm{Ca}_{\mathrm{V}} 1.3$ was determined by immunostaining with anti-HA monoclonal antibody $(\mathrm{mAb}) 72 \mathrm{~h}$ after transfection. GFP-Shank1B plasmid was cotransfected with $\mathrm{HA}-\mathrm{Ca}_{\mathrm{V}} 1.3$ plasmids as indicated. Obtained images were collected with Olympus IX-71 microscope with $40 \times$ objective by Cascade- 650 camera (Rhoper, Tucson, AZ) and analyzed using MetaFluor (Universal Imaging, West Chester, PA) and Adobe PhotoShop (Adobe Systems, San Jose, CA) software packages.

Real-time reverse transcription-PCR. Primary hippocampal neuronal cultures at 10-12 DIV were stimulated by application of $\mathrm{KCl}$ for $30 \mathrm{~s}$, followed by $90 \mathrm{~min}$ incubation in the culture medium, washed twice with PBS, frozen at -80 , and used for RNA extraction by RNAeasy kit (Qiagen, Valencia, CA). The RNA was DNase treated to avoid DNA contamination. Reverse transcription (RT) was done using SuperScriptIII kit (Invitrogen, Carlsbad, CA) using oligo-dT primer according to the instructions of the manufacture. The sample cDNA and control plasmids were preamplified by eight cycles of conventional PCR using a common forward primer GACAGTCATGTTCAATGCAAC (position 5112; GenBank accession number NM017298) and the reverse primers CAGCGGTTTCTCAGTATCACTTG (position 5645; GenBank accession number NM017298) for $\mathrm{Ca}_{\mathrm{V}} 1.3 \mathrm{a}$ ("long” form) and CCATCGTCAGCAAGTTGTGTTCAT (position 5329; GenBank accession number AF370009) for $\mathrm{Ca}_{\mathrm{V}} 1.3 \mathrm{~b}$ ("short" form). Real-time fluorescence-based PCR assay was performed with the LightCycler (Roche Molecular Biochemicals, Indianapolis, IN) using SYBR green with nested primers. The common forward primer for both forms of $\mathrm{Ca}_{\mathrm{V}} 1.3 \mathrm{cDNA}$ was TACGGACGGCTCTCAAGATCAAG (position 5147; GenBank accession number NM017298), and the reverse primer for $\mathrm{Ca}_{\mathrm{V}} 1.3 \mathrm{a}$ (long form) was GACGGTGGGTGGTATTGGTCTGC (position 5589); the reverse primer for $\mathrm{Ca}_{\mathrm{V}} 1.3 \mathrm{~b}$ (short form) was GCGGTAGCTCAGGCAGACAACTC (position 4932; GenBank accession number AF370009). Triplicate runs were performed for the samples, and duplicate runs were performed for each concentration of the control plasmids. A calibration curve was obtained by amplification of $\mathrm{Ca}_{\mathrm{V}} 1.3 \mathrm{a}$ and $\mathrm{Ca}_{\mathrm{V}} 1.3 \mathrm{~b}$ plasmid DNA at concentrations ranging from 10 to 10,000 $\mathrm{mol} / \mu \mathrm{l}$. Template controls were included in each run.

Current recordings in Xenopus oocytes. HA-Ca 1.3 subunits were expressed in Xenopus oocytes as described previously (Bezprozvanny and Tsien, 1995). Briefly, GFP-Shank1B construct (Sala et al., 2003) was subcloned into pcDNA3 vector. RNA species encoding $\mathrm{HA}-\mathrm{Ca}_{\mathrm{V}} 1.3$ and HA$\mathrm{Ca}_{\mathrm{V}} 1.3-\mathrm{T} 1033 \mathrm{Y}$ subunits, $\beta_{3}$ and $\alpha_{2} \delta-1$ subunits, and GFP-Shank1B were synthesized by in vitro transcription procedure with the use of bacteriophage T7 RNA polymerase. Stage V-VI Xenopus oocytes were prepared by collagenase A treatment and injected with cRNA mixtures as indicated. Currents were recorded 4-5 d after cRNA injection in $40 \mathrm{~mm}$ $\mathrm{Ba}^{2+}$ recording solution $\left(40 \mathrm{~mm} \mathrm{Ba}(\mathrm{OH})_{2}, 50 \mathrm{~mm}\right.$ TEA-OH, $2 \mathrm{~mm} \mathrm{KOH}$, 5 mM HEPES, adjusted to $\mathrm{pH} 7.4$ with methanesulfonic acid) by twoelectrode voltage-clamp amplifier (model OC-725A; Warner Instruments, Hamden, CT) controlled by pClamp6 software (Axon Instruments, Foster City, CA). $\mathrm{Ca}^{2+}$ channel openings were induced by $60 \mathrm{~ms}$ step depolarizations from holding potential of $-80 \mathrm{mV}$ to a range of test potentials as indicated. In nifedipine-blocking experiments, the holding potential was $-60 \mathrm{mV}$ and test potential was $+10 \mathrm{mV}$. Collected data were analyzed off-line using pClamp6 software.

pCREB phosphorylation assay. Primary rat hippocampal neuronal cultures (8-10 DIV) were cotransfected with HA-Ca $1.3-\mathrm{T} 1033 \mathrm{Y}$ or HA$\mathrm{Ca}_{\mathrm{V}} 1.3-\mathrm{T} 1033 \mathrm{Y}-\Delta \mathrm{C}$ plasmids and $\beta_{3}$ and $\alpha_{2} \delta$ - 1 subunits. Seventy-two hours after transfection, the neurons were incubated in Tyrode solution in the presence of $1 \mu \mathrm{M}$ TTX, $50 \mu \mathrm{M}$ AP-5, $10 \mu \mathrm{M}$ CNQX, $50 \mu \mathrm{M}$ nifedipine for $3 \mathrm{~h}$, stimulated for $90 \mathrm{~s}$ or $30 \mathrm{~s}$ by application of depolarizing solution in the presence of $1 \mu \mathrm{M}$ TTX, $50 \mu \mathrm{M}$ AP-5, $10 \mu \mathrm{M}$ CNQX, $50 \mu \mathrm{M}$ nifedipine $[20 \mathrm{~mm} \mathrm{KCl}$ in Tyrode (20K); $45 \mathrm{~mm} \mathrm{KCl}$ in Tyrode (45K); 90

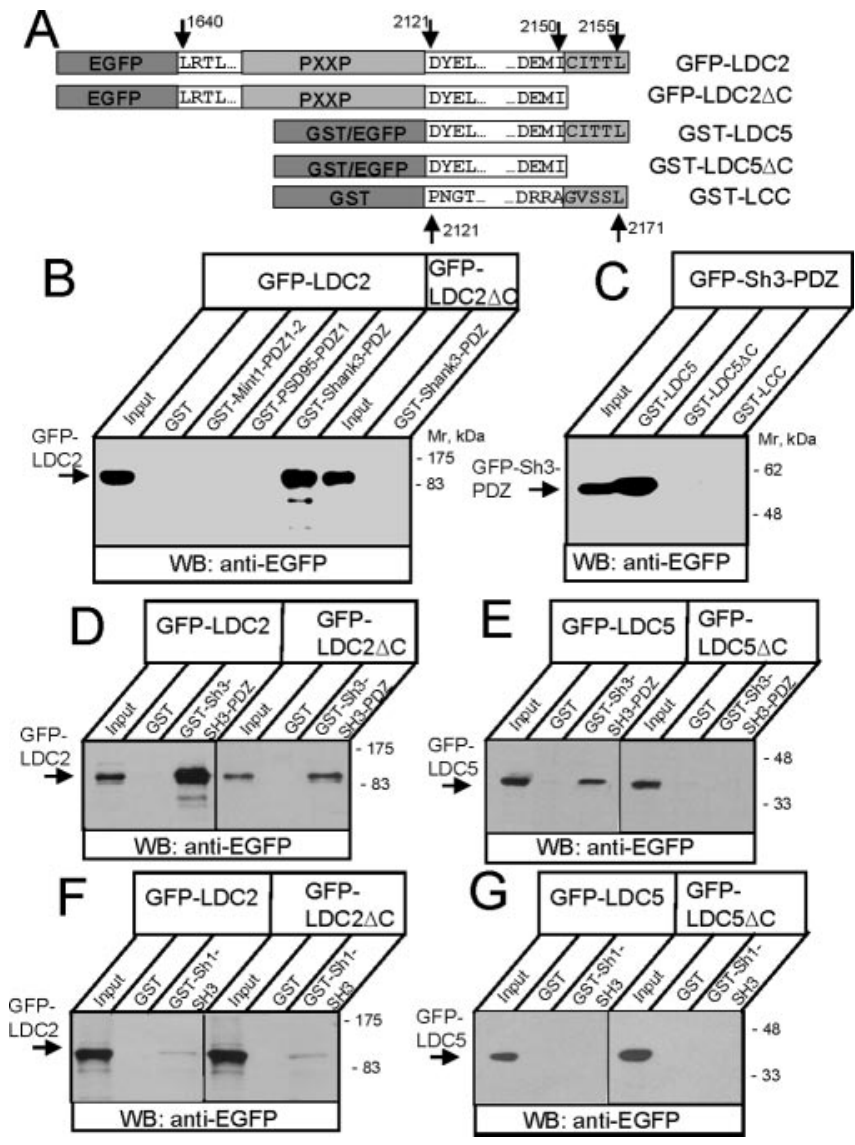

Figure2. $\quad \mathrm{Ca}_{\mathrm{v}} 1.3 \mathrm{a}$ C terminal binds to Shank in vitro. A, Diagram of GFP-LDC2, GST/GFP-LDC5, and GST-LCC fusion proteins. B, GST, GST-Mint1-PDZ1-2, GST-PSD95-PDZ1, and GST-Shank3PDZ were used to pull down GFP-LDC2 and GFP-LDC2 $\triangle$ C from HEK293 cell lysates. C, GST-LDC5, GST-LDC5- $\Delta C$, and GST-LCC were used to pull down GFP-Shank3-PDZ from HEK293 cell lysates. The input lanes in $B$ and $C$ contain 1/50 of HEK293 cell lysates used for pull-down experiments. $D, E$, GST and GST-Shank3-SH3-PDZ were used to pull down GFP-LDC2 and GFP-LDC2 $\Delta C(D)$ or GFP-LDC5 and GFP-LDC5 $\Delta C$ ( $E$ ) from HEK293 cell lysates. F, G, GST and GST-Shank1-SH3 were used to pull down GFP-LDC2 and GFP-LDC2 $\Delta C$ ( F) or GFP-LDC5 and GFP-LDC5 $\Delta C(G)$ from HEK293 cell lysates. The input lane in D (GFP-LDC2 $\Delta C$ ) and $E-G$ contain $1 / 25$ and for $D$ (GFPLDC2) contains $1 / 10$ of HEK293 cell lysates used for pull-down experiments. For $B-G$, the precipitated proteins were recognized by anti-EGFP antibodies.

mM KCl in Tyrode (90K)], fixed, permeabilized, and stained with antipCREB polyclonal antibody $(\mathrm{pAb})$ and anti-HA mAb. In electrical field stimulation (EFS) experiments, the neurons were transferred to Tyrode solution containing $50 \mu \mathrm{M}$ AP-5, $50 \mu \mathrm{M}$ nifedipine, and $20 \mu \mathrm{M}$ bicuculline and stimulated at $5 \mathrm{~Hz}$ frequency by current pulses of $0.5 \mathrm{~mA}$ amplitude and $150 \mu$ s duration [World Precision Instruments (Sarasota, FL) A365 stimulator controlled by Neurolog Digitimer (Hertfordshire, UK)] applied via a pair of platinum electrodes (Bito et al., 1996). Transfected cells were identified by anti-HA mAb staining, and nuclear pCREB $\mathrm{pAb}$ staining was quantified by confocal imaging (Zeiss LS800). The intensity of nuclear pCREB staining in each series of experiments was normalized to mean pCREB signal in unstimulated cells and averaged across different experiments. $\mathrm{Ca}^{2+}$ imaging experiments (DeltaRAM illuminator; Photon Technology International, Lawrenceville, NJ) with primary hippocampal neuronal cultures were performed using fura-2 AM (Molecular Probes, Eugene, OR) as described previously for striatal medium spiny neurons (Tang et al., 2003).

RRRRRRRRR (R9), RRRRRRRRRALPDSRSYVSNL (R9-LCC), RRRRRRRRRLADEMICITTL (R9-LDC), and RRRRRRRRRYEKLSSIESDV (R9-NR2B) peptides were chemically synthesized, coupled to FITC at the $\mathrm{N}$ terminus, and dissolved in PBS. In loading experiments, the R9 peptides were added to rat hippocampal neurons ( $>10$ DIV) for $10 \mathrm{~min}$ at $50 \mu \mathrm{M}$. After loading with R9 peptides, neurons were incubated 
in Tyrode solution in the presence of $1 \mu \mathrm{M}$ TTX, $50 \mu \mathrm{M} \mathrm{AP}-5$, and $10 \mu \mathrm{M}$ CNQX for $3 \mathrm{~h}$ before $90 \mathrm{~s} \mathrm{KCl}$ depolarization. pCREB immunostaining and $\mathrm{Ca}^{2+}$ imaging were performed and analyzed as described above with omission of nifedipine from the depolarizing solution.

Antibodies. Monoclonal antibodies were as follows: anti-synapsin 1 (1:1000; Chemicon, Temecula, CA), anti-GFP (1:1000; Covance, Berkeley, CA), anti-HA (1:1000; HA.11 from Covance). Anti-pCREB pAb (1:1000) was from Upstate Biotechnology (Lake Placid, NY). AntiShank pAb (rabbit-EK3856, 1:1000; guinea pigEK1123, 1:200) was kindly provided by Dr. Eunjoon Kim (KAIST, Daejeon, Korea). The rabbit anti-synapsin pAb (IB2881; 1:1000) were raised against keyhole limpet hemocyaninconjugated NYLRRRLSDSNFMANLPNGYMTDLQRPQP peptide corresponding to $\mathrm{N}$ terminus of Synapsin 1 . The rabbit anti- $\mathrm{Ca}_{\mathrm{V}} 1.3 \mathrm{a}$ pAb (AM9742; 1:250) were generated against GST-LDC5 and affinity purified on Sepharoseconjugated LDC6 peptide (2132-2155 of rat $\left.\mathrm{Ca}_{\mathrm{V}} 1.3 \mathrm{a}\right)$

\section{Results}

$\mathrm{Ca}_{\mathrm{V}}$ 1.3a L-type $\mathrm{Ca}^{2+}$ channel binds Shank-PDZ in yeast two-hybrid system We noticed that the $\mathrm{C}$ termini of long splice variant of neuronal L-type $\mathrm{Ca}^{2+}$ channel subunit $\mathrm{Ca}_{\mathrm{V}} 1.3 \mathrm{a}\left(\alpha_{1 \mathrm{D}-1}\right)$ (Safa et al., 2001; Xu and Lipscombe, 2001) contains a class 1 PDZ domain-binding consensus ITTL (Fig. 1A). Similar consensus sequence VTTL is conserved in Caenorhabditis elegans L-type $\mathrm{Ca}^{2+}$ channels subunit (egl-19) (Fig. 1A). A class 1 PDZ domain-binding motif VSXL is also present in cardiac/neuronal $\mathrm{Ca}_{\mathrm{V}} 1.2\left(\alpha_{1 \mathrm{C}}\right)$ subunit (Fig. 1A), but it is absent in skeletal muscle $\mathrm{Ca}_{\mathrm{V}} 1.1\left(\alpha_{1 \mathrm{~S}}\right)$ and retinal $\mathrm{Ca}_{\mathrm{V}} 1.4$ $\left(\alpha_{1 \mathrm{~F}}\right)$ L-type $\mathrm{Ca}^{2+}$ channels subunits (data not shown). The $\mathrm{C}$ termini of $\mathrm{Ca}_{\mathrm{V}} 1.2$ associates with the PDZ domains of NIL-16 and CIPP proteins (Kurschner et al., 1998; Kurschner and Yuzaki, 1999), but the PDZ binding partners of $\mathrm{Ca}_{\mathrm{V}} 1.3 \mathrm{a}$ have not been described previously. To search for a novel $\mathrm{Ca}_{\mathrm{V}}$ 1.3a-binding partners, we performed a $\mathrm{Y} 2 \mathrm{H}$ screen of rat brain cDNA library with the LDC bait (aa 2142-2155 of rat $\mathrm{Ca}_{\mathrm{V}} 1.3 \mathrm{a}$ ) (Fig. $1 \mathrm{~A}$ ) and isolated 105 positive clones. When 13 isolated clones were chosen randomly and sequenced, we identified five Shank1 clones, two Shank3 clones, two PIST (TC10specific interacting protein) clones, one ZNF198 clone (zinc finger protein 198), and the two clones for hypothetical proteins FLJ23209 and XP_147932. Because 7 of 13 sequenced clones corresponded to the Shank family members, we focused on Shank proteins as physiologically relevant $\mathrm{Ca}_{\mathrm{V}} 1$.3a-binding partners in the remainder of the study.

Shank proteins are modular adaptor proteins that play a role of "master scaffold" in the postsynaptic specializations at glutamatergic synapses (Sheng and Kim, 2000). Three isoforms of Shank proteins are expressed in the brain (Lim et al., 1999) (Fig.
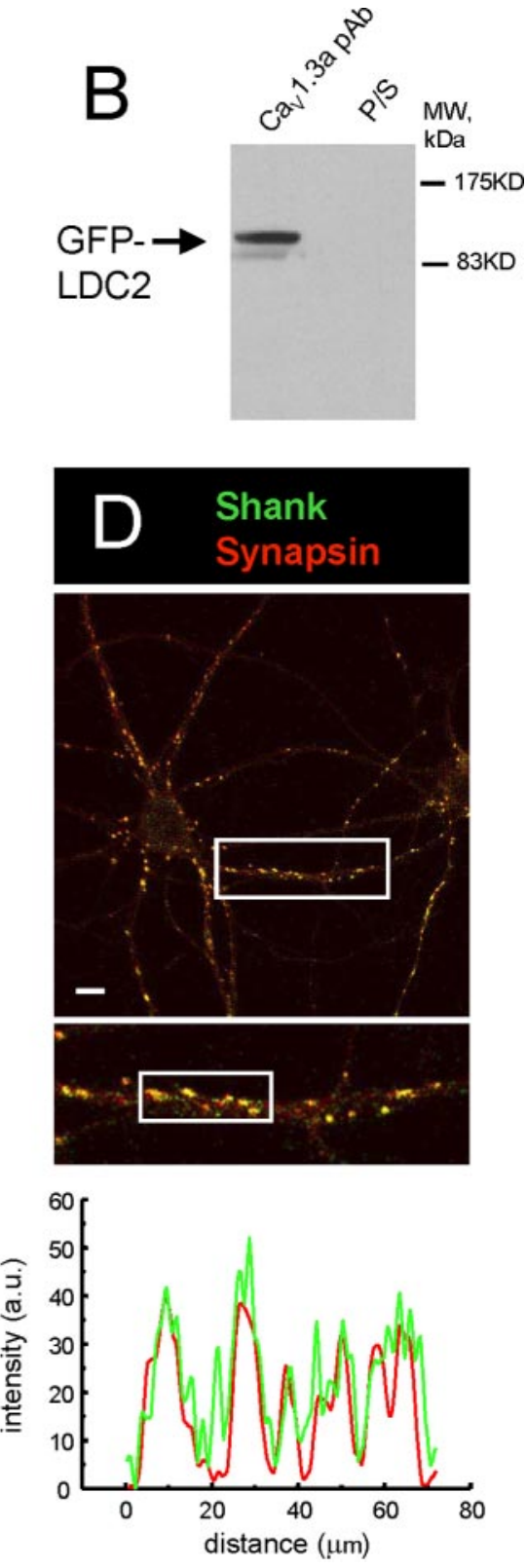

Figure 3. C $C a_{v} 1.3 a$ and Shank colocalize in synaptic locations in vivo. A, Real-time RT-PCR analysis of C $a_{v} 1.3$ C-terminal splice variant transcript abundance in rat hippocampal neuronal cultures. The means of triplicate determinations and SDs of concentrations of $\left(a_{v} 1.3 a\right.$ (open bars) and $a_{v} 1.3 b$ (filled bars) splice variant transcripts are shown for unstimulated neurons and for neurons stimulated by $30 \mathrm{~s} \mathrm{KCl}$ depolarizations as indicated. Ctr, Control. B, Lysates from HEK293 cells transfected with GFP-LDC2 plasmid were analyzed by Western blotting with anti-CaV1.3a pAb (AM9742) or corresponding preimmune sera (P/S).C,D, Rat hippocampal neurons at 12 DIV were stained with anti-Ca $1.3 a$ pAb AM9742 (green) and anti-synapsin mAb (red) ( $C$ ), anti-Shank pAb EK3856 (green), and anti-synapsin mAb (red) (D). Scale bars, $40 \mu \mathrm{m}$. Boxed sections in ( and $D$ are enlarged as indicated and shown below with corresponding profile scans.

$1 B)$. All sequenced Shank1/3 clones contained a PDZ domain (Fig. $1 B$ ), indicating that LDC bait most likely binds to the Shank-PDZ domain. We screened all isolated clones by PCR with the primers specific for Shank1/2/3 PDZ domain sequences and discovered 20 Shank1 clones, no Shank 2 clones, and 59 Shank3 clones. Thus, 79 of 105 clones isolated in the LDC screen $(75.2 \%)$ corresponded to Shank1 and Shank3 proteins. The absence of Shank2 among isolated clones may be related to underrepresentation of Shank2 in cDNA library used for $\mathrm{Y} 2 \mathrm{H}$ screen or unique features of Shank2 PDZ domain. To further characterize $\mathrm{Ca}_{\mathrm{V}}$ 1.3a-Shank interactions, we compared the interaction of 

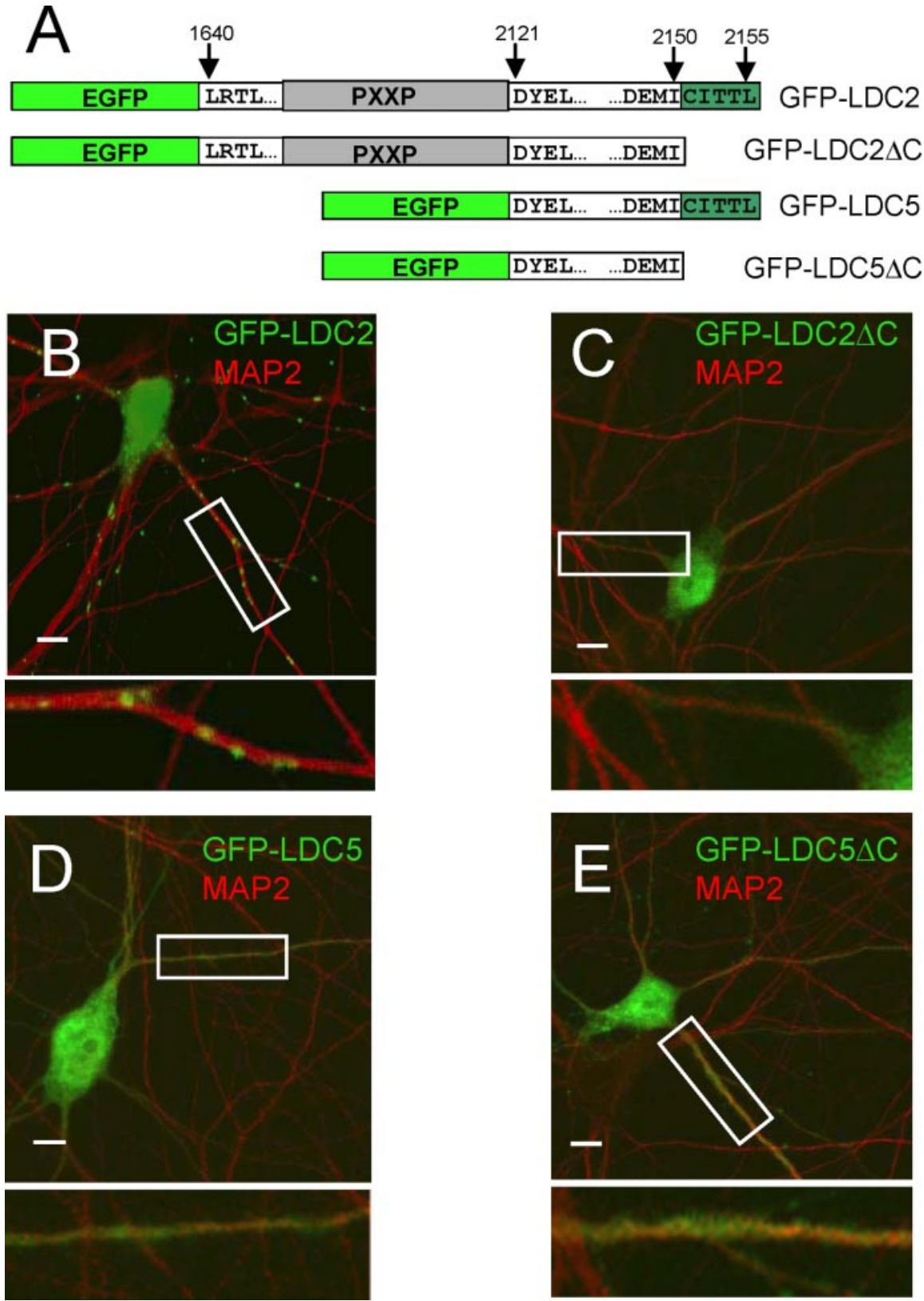

Figure 4. Targeting of GFP-LDC constructs in hippocampal neurons. A, Diagram of GFP-LDC2 and GFP-LDC5 fusion proteins. $B-E$, Subcellular localization of GFP-LDC2 (B), GFP-LDC2 $\Delta C(C)$, GFP-LDC5 (D), and GFP-LDC5 $\Delta C(E)$ expressed in mature hippocampal neurons (green) is compared with MAP2 (red) by confocal imaging. Scale bars, $40 \mu \mathrm{m}$.

LDC bait with Shank1 and Shank3 PDZ domains and with the PDZ domains of SAP-102, PSD-93 (chapsin-110), PSD-95, $\mathrm{Z} 0-1$, and Mint1 proteins in liquid $\mathrm{Y} 2 \mathrm{H}$ assay. From all domains tested, the strongest interaction of LDC bait was observed with Shank3-PDZ domain followed by Shank1-PDZ domain (Fig. $1 C$ ), in agreement with the results of $\mathrm{Y} 2 \mathrm{H}$ screen.

PDZ domains typically bind to the most C-terminal region of the target protein (Songyang et al., 1997). In agreement with this general paradigm, LDC $\Delta \mathrm{C}$ truncation mutant lacking ITTL motif failed to bind Shank3-PDZ domain in $\mathrm{Y} 2 \mathrm{H}$ assay (Fig. $1 D$ ). Analysis of LDC bait point mutants (Fig. 1D) led us to conclude that Shank3-PDZ domain specificity (TXL) fits with the canonical class 1 PDZ domain-binding consensus S/T-X- $\Phi$ (Songyang et al., 1997). This conclusion is in agreement with the assignment of Shank-PDZ domain to (G,H) group (Bezprozvanny and Maxi- mov, 2001), with the previous studies of Shank-PDZ domain ligand specificity (Sheng and Kim, 2000) and with the recently determined crystal structure of Shank-PDZ domain (Im et al., 2003). The $\mathrm{Ca}_{\mathrm{V}} 1.2 \mathrm{~L}$-type $\mathrm{Ca}^{2+}$ channel subunit also contains class 1 PDZ domain-binding motif(Fig. 1A). However, in contrast to LDC bait, LCC bait (aa 2121-2171 of rabbit $\mathrm{Ca}_{\mathrm{V}} 1.2$ ) failed to interact with Shank3-PDZ domain in liquid $\mathrm{Y} 2 \mathrm{H}$ assay (Fig. 1D). The specificity of Shank3PDZ for $\mathrm{Ca}_{V} 1.3$ a $\mathrm{C}$ terminus was determined by the last four amino acids, because LDC-LCC chimeric bait (last four amino acids of LDC bait replaced with VSNL sequence from rat $\mathrm{Ca}_{\mathrm{V}} 1.2$ ) was only weakly associated with Shank3-PDZ domain (Fig. $1 D)$. From the $\mathrm{Y} 2 \mathrm{H}$ analysis, we concluded that Shank-PDZ domain binds strongly and specifically to the $\mathrm{C}$ termini of $\mathrm{Ca}_{\mathrm{V}} 1.3 \mathrm{a}$ subunit.

\section{The $\mathrm{Ca}_{\mathrm{V}}$ 1.3a $\mathrm{C}$ termini binds Shank in vitro}

To independently test for the ability of $\mathrm{Ca}_{V}$ 1.3a C termini to bind Shank PDZ domain, we expressed GFP-LDC2 fusion protein (aa 1640-2155 of rat $\mathrm{Ca}_{\mathrm{V}} 1.3 \mathrm{a}$ ) (Fig. 2A) in HEK293 cells and performed pull-down experiments with GST-fusion proteins of Shank3, PSD-95, and Mint1 PDZ domains expressed in bacteria. We found that GST-Shank3-PDZ, but not other GST-fusion proteins, precipitated GFP-LDC2 (Fig. 2B). In agreement with the $\mathrm{Y} 2 \mathrm{H}$ data, the Shank3-PDZ domain did not precipitate truncated GFPLDC $2 \Delta$ C protein (Fig. $2 B$ ). In a complementary series of experiments, we expressed GFP-Shank3-PDZ domain in HEK293 cells and performed pull-down experiments with GST-LDC5 (aa 2121-2155 of rat $\mathrm{Ca}_{\mathrm{V}} 1.3 \mathrm{a}$ ) (Fig. $2 \mathrm{~A}$ ) and GST-LCC (aa 2121-2171 of rabbit $\mathrm{Ca}_{\mathrm{V}} 1.2$ ) (Fig. 2A) fusion proteins. We found that GST-LDC5, but not GST-LDC5 $\Delta C$ or GST-LCC, precipitated GFP-Shank3-PDZ (Fig. $2 C$ ). Thus, in vitro binding experiments confirmed specific association of Shank3-PDZ domain with $\mathrm{C}$ termini of $\mathrm{Ca}_{\mathrm{V}} 1.3 \mathrm{a}$ subunit.

An additional analysis of $\mathrm{Ca}_{\mathrm{V}} 1.3 \mathrm{a} \mathrm{C}$-terminal sequence revealed a presence of upstream proline-rich region containing five putative SH3 domain-binding sites (PXXP-region) (Fig. 2A). One of these sites $\left({ }^{1906} \mathrm{PPTP}^{1909}\right)$ binds to $\mathrm{SH} 3$ domain of Rimbinding protein (Hibino et al., 2002); binding partners for other sites have not been identified. Shank proteins contain SH3 domain adjacent to PDZ domain (Fig. $1 B$ ), and we reasoned that Shank-SH3 domain may bind to $\mathrm{Ca}_{\mathrm{V}} 1.3$ a C-terminal PXXPregion. In agreement with this idea, we found that GST-Shank3SH3-PDZ quantitatively precipitated GFP-LDC2 (Fig. 2D). GST-Shank3-SH3-PDZ also precipitated GFP-LDC5 and GFPLDC2 $\Delta$ C (Fig. $2 D, E$ ), albeit less efficiently than GFP-LDC2. 
Similar results were obtained in pull-down experiments with GST-Shank1-SH3-PDZ (data not shown). These results can be explained by association of Shank-SH3 domain with PXXP region in LDC2 sequence (Fig. 2A). In agreement with this interpretation, GST-Shank3-SH3-PDZ failed to precipitate GFP-LDC5 $\Delta \mathrm{C}$ (Fig. 2E), which lacks both $\mathrm{PDZ}$ and $\mathrm{SH} 3$ domain interaction motifs (Fig. $2 A$ ). To test this hypothesis directly, we performed pulldown experiments with GST-Shank1-SH3 domain. We discovered that GST-Shank1SH3 domain precipitated GFP-LDC2 and GFP-LDC2 $\Delta$ C (Fig. $2 F$ ) but not GFPLDC5 and GFP-LDC5 $\Delta$ C (Fig. $2 G$ ). We also found that GFP-LDC2 binds to GSTShank1-SH3 with much lower affinity than to GST-Shank3-SH3-PDZ (Fig. 2, compare $F$ and $D$ ), consistent with synergistic contribution of Shank SH3 and PDZ domains to association with $\mathrm{Ca}_{\mathrm{V}} 1.3 \mathrm{a}$ C-terminal region.

\section{$\mathrm{Ca}_{\mathrm{V}}$ 1.3a and Shank colocalize at synaptic locations in hippocampal neurons}

The $\mathrm{Ca}_{\mathrm{V}} 1.3 \mathrm{C}$ terminal is alternatively spliced (Safa et al., 2001; Xu and Lipscombe, 2001). Only the long $\mathrm{Ca}_{\mathrm{V}} 1.3 \mathrm{a}$ splice variant contains Shank-SH3 and Shank-PDZ binding motifs. To determine relative abundance of $\mathrm{Ca}_{\mathrm{V}} 1.3 \mathrm{C}$-terminal splice variants, we extracted RNA from mature rat hippocampal neuronal cultures and performed a series of real-time RTPCR experiments using $\mathrm{Ca}_{\mathrm{V}} 1.3$ C-terminal splice-variant specific primers. We discovered that mRNA for long $\mathrm{Ca}_{\mathrm{V}} 1.3 \mathrm{a}$ C-terminal splice variant was present in $\sim 50$-fold higher abundance in rat hippocampal neurons than short $\mathrm{Ca}_{\mathrm{V}} 1.3 \mathrm{~b}$ form (Fig. $3 \mathrm{~A}$ ) and that $30 \mathrm{~s}$ depolarization of hippocampal neurons by $20 \mathrm{~K}, 45 \mathrm{~K}$, or $90 \mathrm{~K}$ did not induce a significant change in relative abundance of long and short $\mathrm{Ca}_{\mathrm{V}} 1.3$ C-terminal splicevariants (Fig. $3 A$ ). On average, $\mathrm{Ca}_{\mathrm{V}} 1.3 \mathrm{a} / \mathrm{Ca}_{\mathrm{V}} 1.3 \mathrm{~b}$ concentration ratio was $53.6 \pm 6.8$ in control conditions, $40.8 \pm 6.5$ after $20 \mathrm{~K}$ stimulation, $46.2 \pm 15.2$ after $45 \mathrm{~K}$ stimulation, and $40.6 \pm 6.0$ after 90K stimulation (Fig. 3A).

To visualize subcellular localization of $\mathrm{Ca}_{\mathrm{V}} 1$.3a subunit in hippocampal neurons, we generated anti- $\mathrm{Ca}_{\mathrm{V}} 1.3 \mathrm{a}$ rabbit polyclonal antibody (AM9742) against GST-LDC5 antigen. The AM9742 pAb was affinity purified on Sepharose-conjugated LDC6 peptide (2132-2155 of rat $\mathrm{Ca}_{\mathrm{V}} 1.3 \mathrm{a}$ ) and verified in Western blotting experiments with GFP-LDC2 protein expressed in HEK293 cells (Fig. 3B). Generated anti-Ca $\mathrm{V}_{\mathrm{V}} 1.3 \mathrm{a}$ rabbit pAb were used in double-labeling experiments with $\mathrm{mAbs}$ against synapsin. We found that clusters of $\mathrm{Ca}_{\mathrm{V}} 1.3 \mathrm{a}$ immunoreactivity were colocalized with synapsin in mature rat hippocampal neurons (Fig. 3C). The colocalization of $\mathrm{Ca}_{\mathrm{V}} 1.3 \mathrm{a}$ and synapsin clusters was further confirmed by profile scan (Fig. $3 C$ ). In additional double-labeling

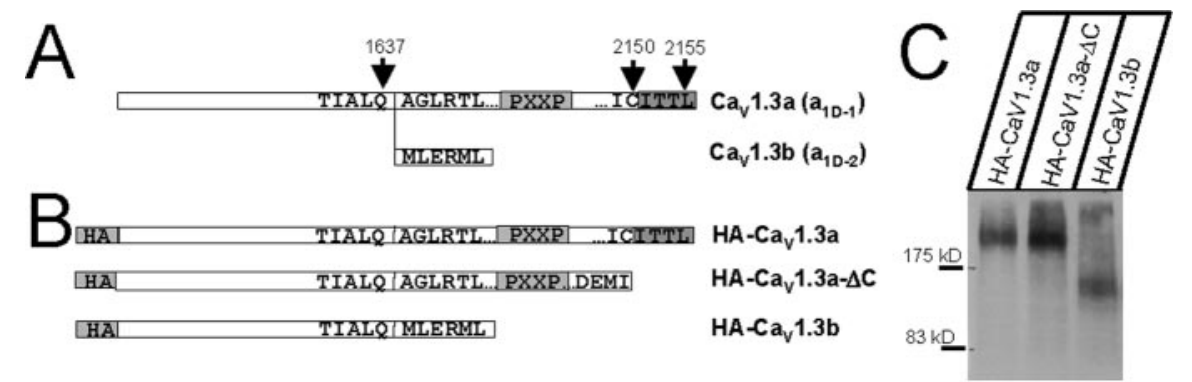

Figure 5. HA-Ca $1.3 \mathrm{~L}_{\mathrm{V}}$ type $\mathrm{Ca}^{2+}$ channel expression constructs. A, Alternative splicing of rat $\mathrm{Ca}_{\mathrm{v}} 1.3$ subunit (Safa et al., 2001; $X u$ and Lipscombe, 2001). The position of alternative splicing $\left(Q^{1637}\right)$ is indicated by an arrow. $B$, The diagram of HA-Ca 1.3 Currents supported by HA-Ca $1.3 \mathrm{a}, \mathrm{HA}-\mathrm{Ca}_{\mathrm{v}} 1.3 \mathrm{a}-\Delta \mathrm{C}$, and HA-Ca $1.3 \mathrm{~b}$ in Xenopus 00 cytes. The currents were evoked by 50 ms pulse (a) $\alpha_{2} \delta-1$ subunits. F, Representative current traces of HA-Ca $1.3 \mathrm{a}$ L-type channels expressed in Xenopus 0ocytes with and without GFP-Shank1B. The currents were evoked by $50 \mathrm{~ms}$ pulse to $+10 \mathrm{mV}$ from a $-80 \mathrm{mV}$ holding potential. $G$, Current-voltage relationship of currents supported by HA-Ca 1 1.3a channels coexpressed in Xenopus 0ocytes with $\beta_{3}$ and $\alpha_{2} \delta$-1 subunits (filled circles) or with $\beta_{3}$ and $\alpha_{2} \delta$-1 subunits and GFP-Shank1B. The peak currents in $E$ and G are shown as mean \pm SEM ( $n \geq 3$ oocytes).

experiments, we confirmed synaptic localization of Shank in hippocampal neuronal cultures (Fig. 3D) as described previously (Naisbitt et al., 1999; Yao et al., 1999). Thus, we concluded that $\mathrm{Ca}_{\mathrm{V}} 1.3 \mathrm{a}$ and Shank are both clustered at synaptic locations in mature hippocampal neuronal cultures. In the accompanying study (Olson et al., 2005), we further demonstrate that $\mathrm{Ca}_{\mathrm{V}} 1.3 \mathrm{a}-$ Shank complex can be immunoprecipitated from rat brain synaptosomal lysates.

\section{Targeting of recombinant $\mathrm{Ca}_{\mathrm{v}} 1.3 \mathrm{~L}-$ type $\mathrm{Ca}^{2+}$ channels in hippocampal neurons}

To evaluate a role of Shank-binding motifs for $\mathrm{Ca}_{\mathrm{V}} 1.3 \mathrm{~L}$-type $\mathrm{Ca}^{2+}$ channel targeting in neurons, we transfected cultured hippocampal neurons with GFP-LDC2 and GFP-LDC5 $\mathrm{Ca}_{\mathrm{V}} 1.3 \mathrm{a}$ C-terminal constructs (Fig. 4A). Subcellular localization of GFPLDC2/5 constructs was visualized by GFP imaging and compared 

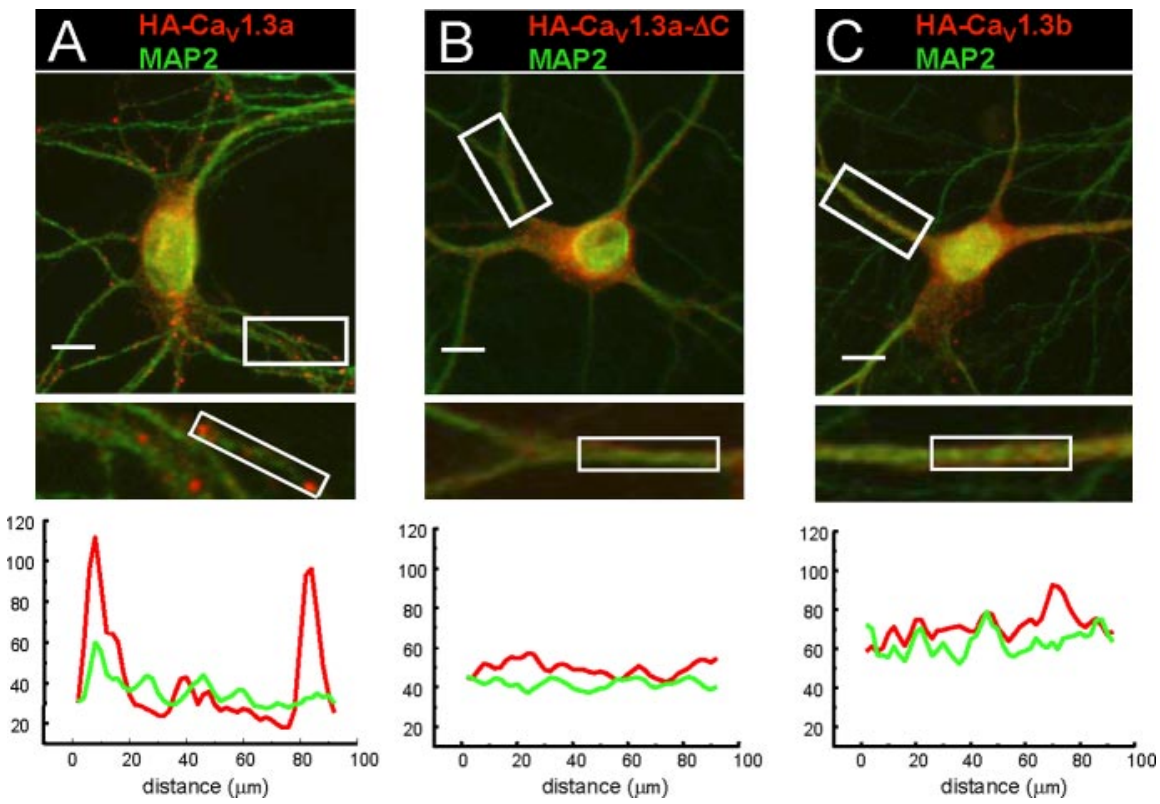

Figure 6. Targeting of recombinant $\mathrm{HA}-\mathrm{C} \mathrm{a}_{\mathrm{v}} 1.3 \mathrm{~L}$-type channels in hippocampal neurons. $A-C$, Subcellular localization of recombinant $\mathrm{HA}-\mathrm{Ca}_{\mathrm{v}} 1.3 \mathrm{~L}$-type $\mathrm{Ca}^{2+}$ channels in hippocampal neurons. Hippocampal neurons were transfected with $\mathrm{HA}-\mathrm{Ca}_{\mathrm{V}} 1.3 /$ $\beta_{3} / \alpha_{2} \delta$-1 plasmid combination at 10 DIV and analyzed $72 \mathrm{~h}$ after transfection by $\mathrm{HA} \mathrm{mAb}$ (red) and MAP2 pAb (green) immunostaining. Results for HA-Ca $1.3 \mathrm{a}(A ; 11$ cells analyzed), HA-Ca $1.3 \mathrm{a}-\Delta C(B ; 15$ cells analyzed), and HA-Ca $1.3 \mathrm{~b}$ ( $C ; 8$ cells analyzed) are shown. Scale bars, $40 \mu \mathrm{m}$. Magnified regions and profile scans are shown below for each panel as indicated.

with MAP2 distribution determined by immunostaining. We found that GFP-LDC2 protein formed clusters in soma and dendrites of transfected neurons (Fig. $4 B$ ) but that GFP-LDC2 $\Delta$ C, GFP-LDC5, and GFP-LDC5 $\Delta$ C were diffusely distributed (Fig. $4 C-E$ ). Our results with GFP-LDC5 protein are consistent with the previously reported diffuse distribution of enhanced GFP (EGFP)-ITTL protein in hippocampal neurons (Weick et al., 2003). From these experiments, we concluded that the presence of both PDZ and $\mathrm{SH} 3$ domain-binding motifs is required to support formation of GFP-LDC2 clusters (Fig. $4 \mathrm{~B}$ ). This result is in contrast to analysis of $\mathrm{Ca}_{\mathrm{V}} 1.2$ targeting (Weick et al., 2003), which demonstrated that the presence of PDZ domain-binding motif was sufficient for clustering of EGFP-VSNL protein in hippocampal neurons.

To compare subcellular localization of L-type $\mathrm{Ca}^{2+}$ channels formed by $\mathrm{Ca}_{\mathrm{V}} 1.3 \mathrm{a}$ and $\mathrm{Ca}_{\mathrm{V}} 1.3 \mathrm{~b}$ pore-forming subunits (Safa et al., 2001; $\mathrm{Xu}$ and Lipscombe, 2001) (Fig. 5A), we generated epitope-tagged $\mathrm{HA}-\mathrm{Ca}_{\mathrm{V}} 1.3 \mathrm{a}, \mathrm{HA}-\mathrm{Ca}_{\mathrm{V}} 1.3 \mathrm{a}-\Delta \mathrm{C}$, and $\mathrm{HA}-\mathrm{Ca}_{\mathrm{V}} 1.3 \mathrm{~b}$ expression constructs (Fig. 5B) (see Materials and Methods for details). In control Western blotting experiments, we determined that $\mathrm{HA}-\mathrm{Ca}_{\mathrm{V}} 1.3 \mathrm{a}, \mathrm{HA}-\mathrm{Ca} \mathrm{V}_{\mathrm{V}} 1.3 \mathrm{a}-\Delta \mathrm{C}$, and $\mathrm{HA}-\mathrm{Ca}_{\mathrm{V}} 1.3 \mathrm{~b}$ subunits expressed at similar levels when transfected into HEK293 cells (Fig. 5C). To confirm functional expression of generated constructs, we coinjected HA-Ca $1.3, \beta_{3}$, and $\alpha_{2} \delta$ - 1 cRNA into $X e$ nopus oocytes and performed a series of two-electrode voltageclamp experiments using $40 \mathrm{mM} \mathrm{Ba}^{2+}$ as a current carrier (see Materials and Methods for details). We found that $\mathrm{HA}-\mathrm{Ca}_{\mathrm{V}} 1.3 \mathrm{a}$ and $\mathrm{HA}-\mathrm{Ca}_{\mathrm{V}} 1.3 \mathrm{a}-\Delta \mathrm{C}$ supported currents of similar amplitude (Fig. 5D) and displayed similar current-voltage relationships (Fig. $5 E$ ). We did not observe a hallmark shift in $\mathrm{Ca}_{\mathrm{V}} 1.3$ voltage dependence in our experiments (Koschak et al., 2001; Xu and Lipscombe, 2001), because our recordings have been performed using $40 \mathrm{~mm} \mathrm{Ba}^{2+}$ as a current carrier, and high concentrations of divalent cations are known to obscure the position of $\mathrm{Ca}_{\mathrm{V}} 1.3$ voltage dependence ( $\mathrm{Xu}$ and Lipscombe, 2001). The currents supported by $\mathrm{HA}-\mathrm{Ca}_{\mathrm{V}} 1.3 \mathrm{~b}$ subunit were approximately twofold larger than the currents supported by $\mathrm{HA}-\mathrm{Ca}_{\mathrm{V}} 1.3 \mathrm{a}$ and $\mathrm{HA}$ $C a_{\mathrm{V}} 1.3 \mathrm{a}-\Delta \mathrm{C}$ subunits (Fig. $5 D, E$ ). These results are consistent with the previous characterization of currents supported by untagged $\mathrm{Ca}_{\mathrm{V}} 1.3 \mathrm{a}$ and $\mathrm{Ca}_{\mathrm{V}} 1.3 \mathrm{~b}$ constructs when expressed in Xenopus oocytes ( $\mathrm{Xu}$ and Lipscombe, 2001). Does association with Shank (Figs. 1, 2) affect $\mathrm{Ca}_{\mathrm{V}} 1.3 \mathrm{a}$ L-type $\mathrm{Ca}^{2+}$ channel gating? To address this question, in the next series of experiments, we coinjected HA-Ca $1.3 \mathrm{a}, \beta_{3}$, and $\alpha_{2} \delta$ - 1 cRNA into Xenopus oocytes with or without GFP-Shank1B cRNA and analyzed resulting currents by two-electrode voltage clamp. We found that neither the shape of the current waveform nor position of the current-voltage relationship of L-type $\mathrm{Ca}^{2+}$ channels formed by HA$\mathrm{Ca}_{\mathrm{V}} 1.3 \mathrm{a}$ subunit was significantly altered in the presence of GFP-Shank1B (Fig. $5 F, G)$. Smaller size of the currents in the presence of GFP-Shank1B (Fig. $5 F, G$ ) most likely reflects lower levels of $\mathrm{Ca}^{2+}$ channel subunit expression when GFPShank1B cRNA is cotranslated in the same Xenopus oocyte.

In the previous study (Maximov and Bezprozvanny, 2002), we used HA-Ca 2.2 constructs to dissect structural determinants of $\mathrm{N}$-type $\mathrm{Ca}^{2+}$ channel targeting in neurons. In the present study, we extended the same approach to analysis of $\mathrm{Ca}_{\mathrm{V}} 1.3 \mathrm{~L}$-type $\mathrm{Ca}^{2+}$ channel neuronal targeting. We coexpressed $\mathrm{HA}-\mathrm{Ca}_{\mathrm{V}} 1.3$, $\beta_{3}$ and $\alpha_{2} \delta$-1 subunits in mature hippocampal neurons cultured at high density and evaluated subcellular localization of HA$\mathrm{Ca}_{\mathrm{V}} 1.3$ channels by immunostaining with anti-HA mAb and anti-MAP2 $\mathrm{pAb}$. We found that recombinant $\mathrm{HA}-\mathrm{Ca}_{\mathrm{V}} 1.3 \mathrm{a}$ channels were concentrated in discrete clusters associated with MAP2positive processes (Fig. 6A). In contrast to $\mathrm{HA}-\mathrm{Ca}_{\mathrm{V}} 1.3 \mathrm{a}$, L-type channels formed by $\mathrm{HA}-\mathrm{Ca}_{\mathrm{V}} 1.3 \mathrm{a}-\Delta \mathrm{C}$ and $\mathrm{HA}-\mathrm{Ca}_{\mathrm{V}} 1.3 \mathrm{~b}$ subunits have not formed distinct puncta in hippocampal neurons (Fig. $6 B, C)$, suggesting an important role of C-terminal PDZ domainbinding motif for $\mathrm{Ca}_{\mathrm{V}} 1.3 \mathrm{a}$ L-type $\mathrm{Ca}^{2+}$ channel clustering.

To further determine an importance of $\mathrm{Ca}_{\mathrm{V}}$ 1.3-Shank association for L-type $\mathrm{Ca}^{2+}$ channel targeting, in the next series of experiments we coexpressed HA-tagged $\mathrm{Ca}_{V} 1.3 \mathrm{~L}$-type $\mathrm{Ca}^{2+}$ channels (HA-Ca $1.3, \beta_{3}$, and $\alpha_{2} \delta$-1) with GFP-Shank1B (Sala et al., 2003) in mature rat hippocampal neurons. In these experiments, subcellular localization of $\mathrm{HA}-\mathrm{Ca}_{\mathrm{V}} 1.3$ subunits is determined by immunostaining with anti-HA mAb and compared with subcellular localization of GFP-Shank1B visualized by GFP imaging. We found that $\mathrm{HA}-\mathrm{Ca}_{\mathrm{V}} 1.3 \mathrm{a}$ subunits were perfectly colocalized with GFP-Shank1B puncta in distal dendrites (Fig. 7A). In contrast to $\mathrm{HA}-\mathrm{Ca}_{\mathrm{V}} 1.3 \mathrm{a}, \mathrm{HA}-\mathrm{Ca}_{\mathrm{V}} 1.3 \mathrm{a}-\Delta \mathrm{C}$ and $\mathrm{HA}-\mathrm{Ca}_{\mathrm{V}} 1.3 \mathrm{~b}$ subunits did not colocalize with GFP-Shank1B puncta (Fig. $7 B, C)$.

Targeting of GFP-Shank1B to postsynaptic spines in mature hippocampal neurons has been extensively documented previously (Sala et al., 2003), and HA-Ca $1.3 \mathrm{a} / \mathrm{GFP}-S h a n k 1 B$ clusters observed in our experiments (Fig. 7A) most likely correspond to synaptic locations. To further test this hypothesis, we stained hippocampal neurons transfected with $\mathrm{HA}-\mathrm{Ca}_{\mathrm{V}} 1.3 \mathrm{a}$ and GFPShank1B using anti-HA mAb and anti-synapsin $\mathrm{pAb}$ and found 
that clusters of recombinant $\mathrm{HA}-\mathrm{Ca}_{\mathrm{V}} 1.3 \mathrm{a}$ and GFP-Shank1B colocalize with endogenous synapsin clusters (Fig. $8 \mathrm{~A}$ ). Colocalization of $\mathrm{HA}-\mathrm{Ca}_{\mathrm{V}} 1.3 \mathrm{a}$, GFP-Shank1B, and synapsin clusters was further confirmed by profile scan analysis (Fig. $8 B$ ). These results are consistent with the previous studies of GFP-Shank1B targeting (Sala et al., 2003) and confirm that HA$\mathrm{Ca}_{\mathrm{V}} 1.3 \mathrm{a} / \mathrm{GFP}-\mathrm{Shank1B}$ clusters are synaptic in origin.

\section{pCREB signaling mediated by recombinant $\mathrm{Ca}_{\mathrm{V}}$ 1.3 L-type $\mathrm{Ca}^{2+}$ channels}

Activation of L-type $\mathrm{Ca}^{2+}$ channels is efficiently coupled to phosphorylation of nuclear transcription factor CREB (Bito et al., 1996; Dolmetsch et al., 2001; Weick et al., 2003). Coupling of $\mathrm{Ca}_{\mathrm{V}} 1.2$ L-type $\mathrm{Ca}^{2+}$ channels to pCREB has been demonstrated in experiments with dihydropyridine-resistant (DHPR) $\mathrm{Ca}_{\mathrm{V}} 1.2 \mathrm{~L}$ type $\mathrm{Ca}^{2+}$ channels containing T1039Y mutation (He et al., 1997; Dolmetsch et al., 2001; Weick et al., 2003). To evaluate a contribution of $\mathrm{Ca}_{\mathrm{V}} 1.3 \mathrm{Ca}^{2+}$ channels to pCREB signaling, we adapted the "pharmacological knock-out" strategy from Dolmetsch et al. (2001). Primary sequence alignment reveals a high degree of sequence conservation between $\mathrm{Ca}_{\mathrm{V}} 1.2$ and $\mathrm{Ca}_{\mathrm{V}} 1.3$ subunits in the region surrounding $\mathrm{Ca}_{\mathrm{V}}$ 1.2-T1039 residue (Fig. 9A). Thus, to obtain DHPR-Ca 1.3 channel, we generated an analogous T1033Y mutation in the $\mathrm{Ca}_{V} 1.3$ sequence (Fig. 9A). To visualize DHPR-Ca 1.3 channels in neurons, we subcloned a fragment containing T1033Y mutation to $\mathrm{HA}-\mathrm{Ca}_{\mathrm{V}} 1.3$ targeting constructs (Fig. 5B) and generated $\mathrm{HA}-\mathrm{Ca}_{\mathrm{V}} 1.3 \mathrm{a}-$ T1033Y and HA-Ca $1.3 \mathrm{a}-\mathrm{T} 1033 \mathrm{Y}-\Delta \mathrm{C}$ constructs. In control Xenopus oocyte expression experiments, we found that 100 $\mu \mathrm{M}$ nifedipine efficiently inhibited L-type currents supported by the $\mathrm{HA}-\mathrm{Ca}_{\mathrm{V}} 1.3 \mathrm{a}$ subunit (Fig. 9B, top) but had a much smaller effect on the currents supported by HA-Ca $1.3 \mathrm{a}-\mathrm{T} 1033 \mathrm{Y}$ and $\mathrm{HA}-\mathrm{Ca}_{\mathrm{V}} 1.3 \mathrm{a}-\mathrm{T} 1033 \mathrm{Y}-\Delta \mathrm{C}$ subunits (Fig. 9B, middle, bottom). Thus, in agreement with the sequence alignment (Fig. 9A), $\mathrm{Ca}_{\mathrm{V}}$ 1.3-T1033Y mutant is functionally analogous to $\mathrm{Ca}_{\mathrm{V}} 1.2-$ T1039Y and indeed encodes DHPR-Ca $\mathrm{V}_{\mathrm{V}} 1.3 \mathrm{~L}$-type $\mathrm{Ca}^{2+}$ channel. These results are consistent with the recently reported description of DHPR-Ca 1.3 double mutant containing T1033Y and Q1037M substitutions (Liu et al., 2003). In additional control experiments, we demonstrated that L-type channels supported by $\mathrm{HA}-\mathrm{Ca}_{\mathrm{V}} 1.3 \mathrm{a}-\mathrm{T} 1033 \mathrm{Y}$ and $\mathrm{HA}-\mathrm{Ca}_{\mathrm{V}} 1.3 \mathrm{a}-\mathrm{T} 1033 \mathrm{Y}-\Delta \mathrm{C}$ subunits display similar current-voltage relationship when expressed in Xenopus oocytes (Fig. 9C).

Functional expression of L-type channels supported by $\mathrm{HA}-\mathrm{Ca}_{\mathrm{V}} 1.3 \mathrm{a}-\mathrm{T} 1033 \mathrm{Y}$ and $\mathrm{HA}-\mathrm{Ca}_{\mathrm{V}} 1.3 \mathrm{a}-\mathrm{T} 1033 \mathrm{Y}-\Delta \mathrm{C}$ subunits in hippocampal neurons was further evaluated by fura- $2 \mathrm{Ca}^{2+}$ imaging. In these experiments, HA-Ca $1.3 \mathrm{a}-\mathrm{T} 1033 \mathrm{Y}$ or HA-
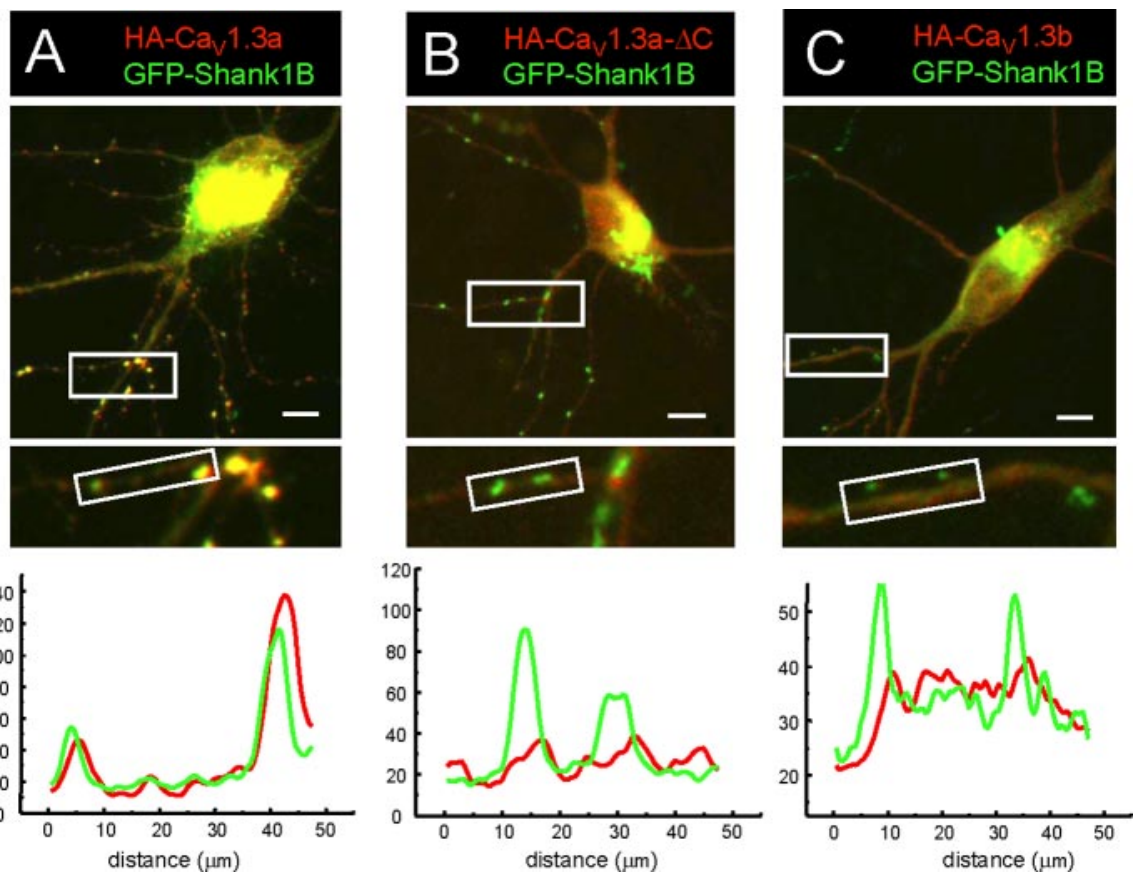

Figure 7. Targeting of recombinant HA-Ca 1.3 L-type $\mathrm{Ca}^{2+}$ channels and GFP-Shank in hippocampal neurons. A-C, Hippocampal neurons were cotransfected with $\mathrm{HA}-\mathrm{C} \mathrm{a}_{\mathrm{V}} 1.3 / \beta_{3} / \alpha_{2} \delta$-1 plasmids and GFP-Shank1B at $9 \mathrm{DIV}$ and analyzed $72 \mathrm{~h}$ after transfection by anti-HA mAb immunostaining (red) and GFP imaging (green). Results for HA-Ca $1.3 a$ ( $A$; 11 cells analyzed), $H A-C a_{v} 1.3 a-\Delta C(B ; 9$ cells analyzed), and HA-Ca $1.3 b$ ( $C ; 8$ cells analyzed) are shown. Scale bars, $40 \mu \mathrm{m}$. Magnified regions and
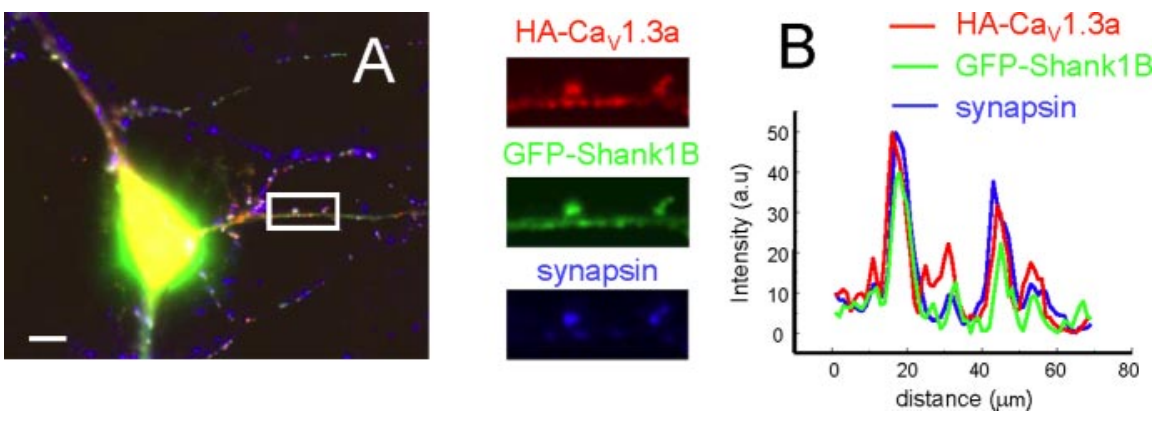

Figure 8. Recombinant HA-C $\mathrm{a}_{\mathrm{v}} 1$.3a L-type $\mathrm{Ca}^{2+}$ channels and GFP-Shank cluster at synaptic locations in hippocampal neurons. A, Hippocampal neurons were cotransfected with $\mathrm{HA}-\mathrm{Ca}_{\mathrm{V}} 1.3 / \beta_{3} / \alpha_{2} \delta-1$ plasmids and GFP-Shank1B at 9 DIV and analyzed $72 \mathrm{~h}$ after transfection by anti-HA mAb immunostaining (red) and GFP imaging (green) and anti-synapsin pAb staining (blue). Scale bar, $40 \mu \mathrm{m}$. The magnified region for each channel is shown as indicated. B, Profile scan of HA-Ca $1.3 a$ (red), GFP-Shank1B (green), and synapsin (blue) signal intensities in the magnified region. Similar results have been obtained with 18 cells analyzed.

$\mathrm{Ca}_{\mathrm{V}} 1.3 \mathrm{a}-\mathrm{T} 1033 \mathrm{Y}-\Delta \mathrm{C}$ subunits were cotransfected into mature hippocampal neurons together with $\beta_{3}$ and $\alpha_{2} \delta$-1 subunits and EGFP plasmid. Transfected neurons were identified by GFP imaging, and $\mathrm{Ca}^{2+}$-imaging experiments with fura-2 were performed as we described previously for striatal medium spiny neurons (Tang et al., 2003) in the presence of $50 \mu \mathrm{M}$ nifedipine, 50 $\mu \mathrm{M}$ D-AP-5, and $10 \mu \mathrm{M}$ CNQX to block $\mathrm{Ca}^{2+}$ influx via endogenous L-type $\mathrm{Ca}^{2+}$ channels, NMDA, and AMPA receptors. We found that $60 \mathrm{~s}$ stimulation by $20 \mathrm{~K}$ or $45 \mathrm{~K}$ depolarizations resulted in greater $\mathrm{Ca}^{2+}$ elevation in transfected (GFP positive) neurons than in untransfected (GFP negative) neurons (Fig. 9D). In either stimulation conditions, we have not observed significant difference in total $\mathrm{Ca}^{2+}$ influx supported by $\mathrm{HA}-\mathrm{Ca}_{\mathrm{V}} 1.3 \mathrm{a}-$ T1033Y and HA-Ca $1.3 \mathrm{a}-\mathrm{T} 1033 \mathrm{Y}-\Delta \mathrm{C}$ subunits (Fig. 9D).

To evaluate the contribution of $\mathrm{Ca}_{\mathrm{V}} 1.3 \mathrm{~L}$-type $\mathrm{Ca}^{2+}$ channels to pCREB signaling, we coexpressed HA-Ca $1.3 \mathrm{a}-\mathrm{T} 1033 \mathrm{Y}$ or 


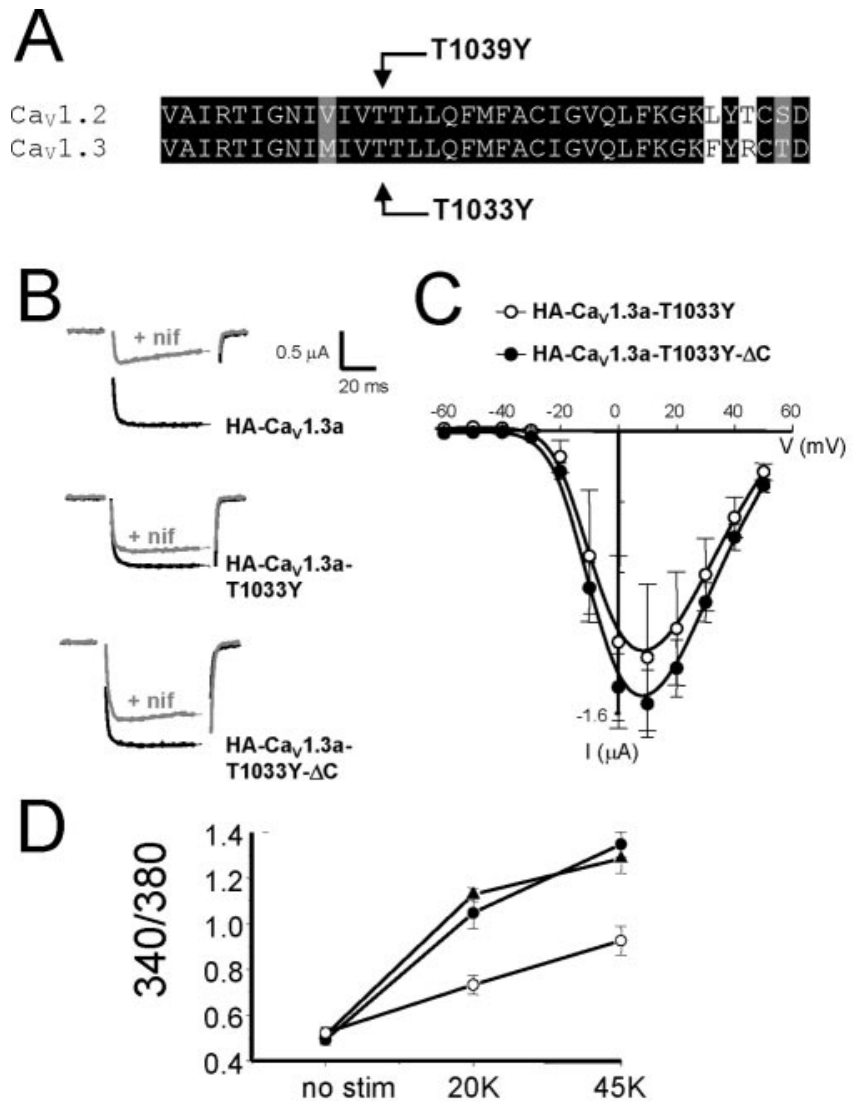

- HA-Cav1.3a-T1033Y $\Delta \mathrm{HA}_{\mathrm{Y}} \mathrm{Ca}_{\mathrm{v}} 1.3 \mathrm{a}-\mathrm{T} 1033 \mathrm{Y}-\Delta \mathrm{C}$ o untransfected

Figure 9. DHP-resistant HA-Ca $1.3 \mathrm{~L}$-type $\mathrm{Ca}^{2+}$ channels. A, Primary sequence alignment of DHP-binding site in $\mathrm{Ca}_{\mathrm{v}} 1.2$ and $\mathrm{Ca}_{\mathrm{v}} 1.3$ subunits. Positions of $\mathrm{Ca}_{\mathrm{v}} 1$ 1.2-T1039Y (He et al., 1997) and $\mathrm{C}_{\mathrm{V}} 1$.3-T1033Y mutations are indicated. B, Representative current traces of L-type currents supported by HA-Ca 1 1.3a (top), HA-Ca $1.3 \mathrm{a}-\mathrm{T} 1033 \mathrm{Y}$ (middle), and HA-Ca $1.3 \mathrm{a}-\mathrm{T} 1033 \mathrm{Y}-\Delta \mathrm{C}$ (bottom) in Xenopus 0ocytes. The currents were evoked by a $50 \mathrm{~ms}$ pulse to $+10 \mathrm{mV}$ from a $-60 \mathrm{mV}$ holding potential. The recordings from the same oocytes obtained before (black traces) and $3 \mathrm{~min}$ after (gray traces) application of $100 \mu \mathrm{m}$ nifedipine are shown. C, Currentvoltage relationship of currents supported by HA-Ca $1.3 \mathrm{a}-\mathrm{T} 1033 \mathrm{Y}$ (open circles) and HA$C a_{v} 1$.3a-T1033Y- $\Delta$ C (filled circles) channels coexpressed in Xenopus 0ocytes with $\beta_{3}$ and $\alpha_{2} \delta$-1 subunits. The peak currents are shown as mean \pm SEM $(n=200$ cytes).D, Hippocampal neurons were transfected with $\mathrm{HA}-\mathrm{Ca}_{\mathrm{V}} 1.3 \mathrm{a}-\mathrm{T} 1033 \mathrm{Y}$ or $\mathrm{HA}-\mathrm{Ca}_{\mathrm{V}} 1.3 \mathrm{a}-\mathrm{T} 1033 \mathrm{Y}-\Delta \mathrm{C}$ plasmids with $\alpha_{2} \delta-1$ and $\beta_{3}$ auxiliary subunits and pEGFP-C3 plasmid. Forty-eight hours after transfection, neurons were loaded with fura- 2 and stimulated for $60 \mathrm{~s}$ with $20 \mathrm{~mm} \mathrm{KCl}(20 \mathrm{~K})$ or $45 \mathrm{~mm} \mathrm{KCl}$ (45K) in the presence of $1 \mu \mathrm{m} \mathrm{TTX,} 50 \mu \mathrm{m}$ nifedipine, $50 \mu \mathrm{m}$ D-AP-5, and $10 \mu \mathrm{m}$ CNQX. An average peak $340 / 380$ ratio in transfected neurons (GFP positive) is shown for $\mathrm{Ca}_{\mathrm{V}} 1.3 \mathrm{a}-\mathrm{T} 1033 \mathrm{Y}$ (filled circles; $n \geq 7$ ) and HA-Ca 1.3a-T1033Y- $\Delta$ C (filled triangles; $n \geq 5$ ) constructs and for nontransfected (GFP negative) neurons (open circles; $n \geq 13$ ) as a function of stimulation.

HA-Ca $1.3 \mathrm{a}-\mathrm{T} 1033 \mathrm{Y}-\Delta \mathrm{C}$ constructs with $\beta_{3}$ and $\alpha_{2} \delta$ - 1 subunits in mature hippocampal neurons. Transfected neurons were stimulated for $90 \mathrm{~s}$ by $\mathrm{KCl}$-induced depolarization $(20 \mathrm{~K}, 45 \mathrm{~K}$, or $90 \mathrm{~K}$ in the continuous presence of $50 \mu \mathrm{M}$ nifedipine, $50 \mu \mathrm{M}$ D-AP-5, and $10 \mu \mathrm{M}$ CNQX) and stained with pCREB-specific pAb (Fig. $10 A)$. The transfected neurons were identified by immunostaining with anti-HA mAb (Fig. 10A). We discovered that $20 \mathrm{~K}$ stimulation induced significant nuclear pCREB signals in neurons transfected with $\mathrm{HA}-\mathrm{Ca}_{\mathrm{V}} 1.3 \mathrm{a}-\mathrm{T} 1033 \mathrm{Y}$ but not in neurons transfected with $\mathrm{HA}-\mathrm{Ca}_{\mathrm{V}} 1.3 \mathrm{a}-\mathrm{T} 1033 \mathrm{Y}-\Delta \mathrm{C}$ (Fig. $10 \mathrm{~A}$ ). In contrast, $45 \mathrm{~K}$ (Fig. $10 A$ ) and $90 \mathrm{~K}$ (data not shown) induced similar nuclear pCREB responses in both groups of transfected cells. The pCREB signals observed in some HA-negative neurons (Fig. 10A) most likely result from the failure to identify low-expressing trans- fected cells by HA immunostaining and/or from incomplete block of endogenous L-type $\mathrm{Ca}^{2+}$ channels by $50 \mu \mathrm{M}$ nifedipine.

For quantitative evaluation of pCREB signaling responses, the intensity of nuclear pCREB staining in stimulated neurons was normalized to the intensity of nuclear pCREB staining in unstimulated neurons measured in the same experiment, and the normalized pCREB values from different experiments were averaged together. An average stimulation-induced increase in nuclear pCREB staining ( $\triangle \mathrm{pCREB})$ is shown as a function of stimulation intensity for neurons transfected with $\mathrm{HA}-\mathrm{Ca}_{\mathrm{V}} 1.3 \mathrm{a}-$ T1033Y or HA-Ca $\mathrm{V}_{\mathrm{V}} 1.3 \mathrm{a}-\mathrm{T} 1033 \mathrm{Y}-\Delta \mathrm{C}$ constructs and for untransfected (HA negative) neurons (Fig. 10B). It is apparent that at high intensities of stimulation ( $45 \mathrm{~K}$ and $90 \mathrm{~K}$ ), both constructs efficiently supported signaling to pCREB, with $>150 \%$ stimulation-induced increase in pCREB nuclear staining in transfected neurons (Fig. $10 \mathrm{~B}$ ). However, at low intensity of stimulation (20K), only HA-Ca $\mathrm{V}_{\mathrm{V}} 1.3 \mathrm{a}-\mathrm{T} 1033 \mathrm{Y}$ construct efficiently supported CREB phosphorylation, whereas $\mathrm{HA}-\mathrm{Ca}_{\mathrm{V}} 1.3 \mathrm{a}-\mathrm{T} 1033 \mathrm{Y}-\Delta \mathrm{C}$ construct was much less effective (Fig. $10 \mathrm{~B}$ ). To explore these differences further, we shortened the duration of $\mathrm{KCl}$ depolarization to $30 \mathrm{~s}$ and repeated the analysis of nuclear pCREB responses. We found that at $30 \mathrm{~s}$ stimulation, the HA-Ca $1.3 \mathrm{a}-\mathrm{T} 1033 \mathrm{Y}$ construct was significantly more efficient in coupling to pCREB than $\mathrm{HA}-\mathrm{Ca}_{\mathrm{V}} 1.3 \mathrm{a}-\mathrm{T} 1033 \mathrm{Y}-\Delta \mathrm{C}$ construct at $20 \mathrm{~K}$ and $45 \mathrm{~K}$ but not at 90K stimulation (data not shown).

To determine the importance of $\mathrm{Ca}_{\mathrm{V}} 1.3 \mathrm{a}$ C-terminal PDZ domain-binding motif for pCREB signaling induced by synaptic activity, the $\mathrm{HA}-\mathrm{Ca}_{\mathrm{V}} 1.3 \mathrm{a}-\mathrm{T} 1033 \mathrm{Y}$ or $\mathrm{HA}-\mathrm{Ca}_{\mathrm{V}} 1.3 \mathrm{a}-\mathrm{T} 1033 \mathrm{Y}-\Delta \mathrm{C}$ transfected neurons were challenged by EFS. These experiments were performed in the continuous presence of $50 \mu \mathrm{M}$ nifedipine and $50 \mu \mathrm{M}$ D-AP-5 to inhibit $\mathrm{Ca}^{2+}$ influx mediated by endogenous L-type $\mathrm{Ca}^{2+}$ channels and NMDAR. Neurons were stimulated by EFS at $5 \mathrm{~Hz}$ frequency for 45 or $180 \mathrm{~s}$ and stained with pCREB-specific pAb and anti-HA mAb. Obtained results were evaluated and quantified as described above for $\mathrm{KCl}$ depolarization experiments. We discovered that L-type $\mathrm{Ca}^{2+}$ channels formed by $\mathrm{HA}-\mathrm{Ca}_{\mathrm{V}} 1.3 \mathrm{a}-\mathrm{T} 1033 \mathrm{Y}$ subunit efficiently supported pCREB responses induced by synaptic activity (Fig. 10C). In contrast, L-type $\mathrm{Ca}^{2+}$ channels formed by HA-Ca $a_{V} 1.3 \mathrm{a}-\mathrm{T} 1033 \mathrm{Y}-\Delta \mathrm{C}$ subunit were much less effective at both 45 and $180 \mathrm{~s}$ EFS (Fig. $10 C$ ), indicating that association of $\mathrm{Ca}_{\mathrm{V}} 1.3 \mathrm{a}$ subunit with PDZ proteins plays an important role in L-type-mediated synaptic signaling to pCREB.

\section{pCREB signaling mediated by endogenous L-type $\mathrm{Ca}^{2+}$ channels}

In the next series of experiments, we evaluated an importance of endogenous $\mathrm{Ca}_{\mathrm{V}} 1.3 \mathrm{a}$ and $\mathrm{Ca}_{\mathrm{V}} 1.2 \mathrm{~L}$-type $\mathrm{Ca}^{2+}$ channel association with PDZ proteins for PCREB signaling by using dominantnegative peptides. In these experiments, we took an advantage of recently developed protein delivery technology (Schwarze et al., 2000) and used R9 signal (Wender et al., 2000; Tang and Bezprozvanny, 2004) to deliver FITC-labeled R9-LCC and R9-LDC competitive peptides and $\mathrm{R} 9$ control peptide into hippocampal neurons. As an additional control for specificity of observed effects, we used R9-NR2B peptide containing class 1 PDZ domainbinding motif from the NR2B NMDAR subunit. As determined by FITC fluorescence, $>90 \%$ of hippocampal neurons were loaded with R9 peptides in our experiments (Fig. 11A), similar to our previous results with striatal medium spiny neurons (Tang and Bezprozvanny, 2004). Three hours after R9 peptides loading, hippocampal neurons were stimulated for $90 \mathrm{~s}$ by $\mathrm{KCl}$ depolarization $(20 \mathrm{~K}$ or $45 \mathrm{~K})$ in the presence of $50 \mu \mathrm{M}$ D-AP- 5 and $10 \mu \mathrm{M}$ 
CNQX to block $\mathrm{Ca}^{2+}$ influx via NMDA and AMPA receptors. Using fura-2 $\mathrm{Ca}^{2+}$ imaging, we determined that total $\mathrm{KCl}$ induced $\mathrm{Ca}^{2+}$ influx was not significantly different in hippocampal neurons loaded with R9, R9-LDC, and R9-LCC peptides (Fig. $11 B$ ).

The effects of R9 competitive peptides on nuclear pCREB signaling were quantified by immunostaining with pCREBspecific pAb as described above for recombinant DHPR-Ca $\mathrm{V}_{\mathrm{V}} 1.3$ L-type $\mathrm{Ca}^{2+}$ channels. We found that pCREB signaling pathway was efficiently activated in R9loaded neurons by either $20 \mathrm{~K}$ or $45 \mathrm{~K}$ stimulation for $90 \mathrm{~s}$ (Fig. 11C). To compare results from different series of experiments, $\Delta$ pCREB signal at each experiment was normalized to an average $\Delta$ pCREB signal induced by application of $45 \mathrm{~K}$ to control neurons (no R9 peptide added) in the same experiment. Quantitative analysis revealed that PCREB signals were not significantly different in R9-loaded and control neurons in $20 \mathrm{~K}$ and $45 \mathrm{~K}$ stimulation conditions (Fig. 11D). However, when compared with R9-loaded neurons, pCREB responses in R9-LCC-loaded neurons were suppressed in both stimulating conditions (Fig. 11C,E). For R9-LDCloaded neurons, the pCREB stimulation was almost completely suppressed at $20 \mathrm{~K}$ stimulation (Fig. 11C,E) but was restored to almost full response at $45 \mathrm{~K}$ stimulation (Fig. 11C,E). When R9-LDC and R9-LCC peptides were combined, pCREB signals were completely suppressed at both $20 \mathrm{~K}$ and $45 \mathrm{~K}$ stimulation conditions (Fig. $11 C, E)$. The observed effects were specific for $\mathrm{Ca}_{\mathrm{V}} 1.3 \mathrm{a}$ and $\mathrm{Ca}_{\mathrm{V}} 1.2 \mathrm{~L}$-type $\mathrm{Ca}^{2+}$ channels C-terminal sequences, because R9NR2B peptide had no effect on $\mathrm{pCREB}$ signaling in our experimental conditions (Fig. 11C,D).

\section{Discussion}

\section{Interactions with modular adaptor}

proteins and synaptic targeting of $\mathrm{Ca}^{2+}$ channels

N-type $\left(\mathrm{Ca}_{\mathrm{V}} 2.2\right)$ and P/Q-type $\left(\mathrm{Ca}_{\mathrm{V}} 2.1\right)$ voltage-gated $\mathrm{Ca}^{2+}$ channels couple membrane depolarization with $\mathrm{Ca}^{2+}$ influx and synaptic vesicle fusion in the presynaptic terminal (Dunlap et al., 1995). In contrast, L-type $\left(\mathrm{Ca}_{\mathrm{V}} 1.2\right.$ and $\left.\mathrm{Ca}_{\mathrm{V}} 1.3\right)$ $\mathrm{Ca}^{2+}$ channels couple membrane depolarization with $\mathrm{Ca}^{2+}$ influx and activation of pCREB and NF-ATc4 transcription factors in the nucleus of a postsynaptic neuron (Bito et al., 1996; Graef et al., 1999; Dolmetsch et al., 2001; Deisseroth et al., 2003; Weick et al., 2003). Because of the highly compartmentalized nature of neuronal $\mathrm{Ca}^{2+}$ signaling, proper subcellular localization of $\mathrm{Ca}^{2+}$ channels is likely to be of critical importance for their function in neurons. Our previous results (Maximov et al., 1999; Maximov and Bezprozvanny, 2002), results by Weick at al. (2003), and the data described in the present report suggest that association of $\mathrm{C}$ termini of $\mathrm{Ca}^{2+}$ channels pore-forming subunit with modular adaptor proteins plays a key role in their neuronal localization. In the previous study (Maximov et al., 1999), we described a C-terminal association of $\mathrm{Ca}_{\mathrm{V}} 2.2\left(\mathrm{~N}\right.$-type) and $\mathrm{Ca}_{\mathrm{V}} 2.1$ (P/Qtype) $\mathrm{Ca}^{2+}$ channel subunits with the first PDZ domain of presynaptic adaptor protein Mint1 and with the $\mathrm{SH} 3$ domain of adaptor protein calcium calmodulin-associated serine/kinase (CASK). In the present report, we describe C-terminal association of $\mathrm{Ca}_{\mathrm{V}} 1.3$ (L-type) $\mathrm{Ca}^{2+}$ channel subunit with $\mathrm{PDZ}$ and $\mathrm{SH} 3$ domains of Shank postsynaptic adaptor protein.

It is interesting to compare $\mathrm{Ca}_{\mathrm{V}} 1.3$ (L-type) association with Shank and $\mathrm{Ca}_{\mathrm{V}} 2.2$ (N-type) association with Mint and CASK. The association of $\mathrm{Ca}_{\mathrm{V}} 2.2$ subunit with Mint-PDZ1 domain is mediated by a novel PDZ domain-binding motif DHWC (Maximov et al., 1999; Bezprozvanny and Maximov, 2001). In contrast, the association of $\mathrm{Ca}_{\mathrm{V}} 1.3$ subunit with Shank-PDZ domain is mediated by a "canonical" class 1 PDZ domain-binding consensus ITTL (Figs. 1, 2). Upstream of PDZ domain-binding motif, 


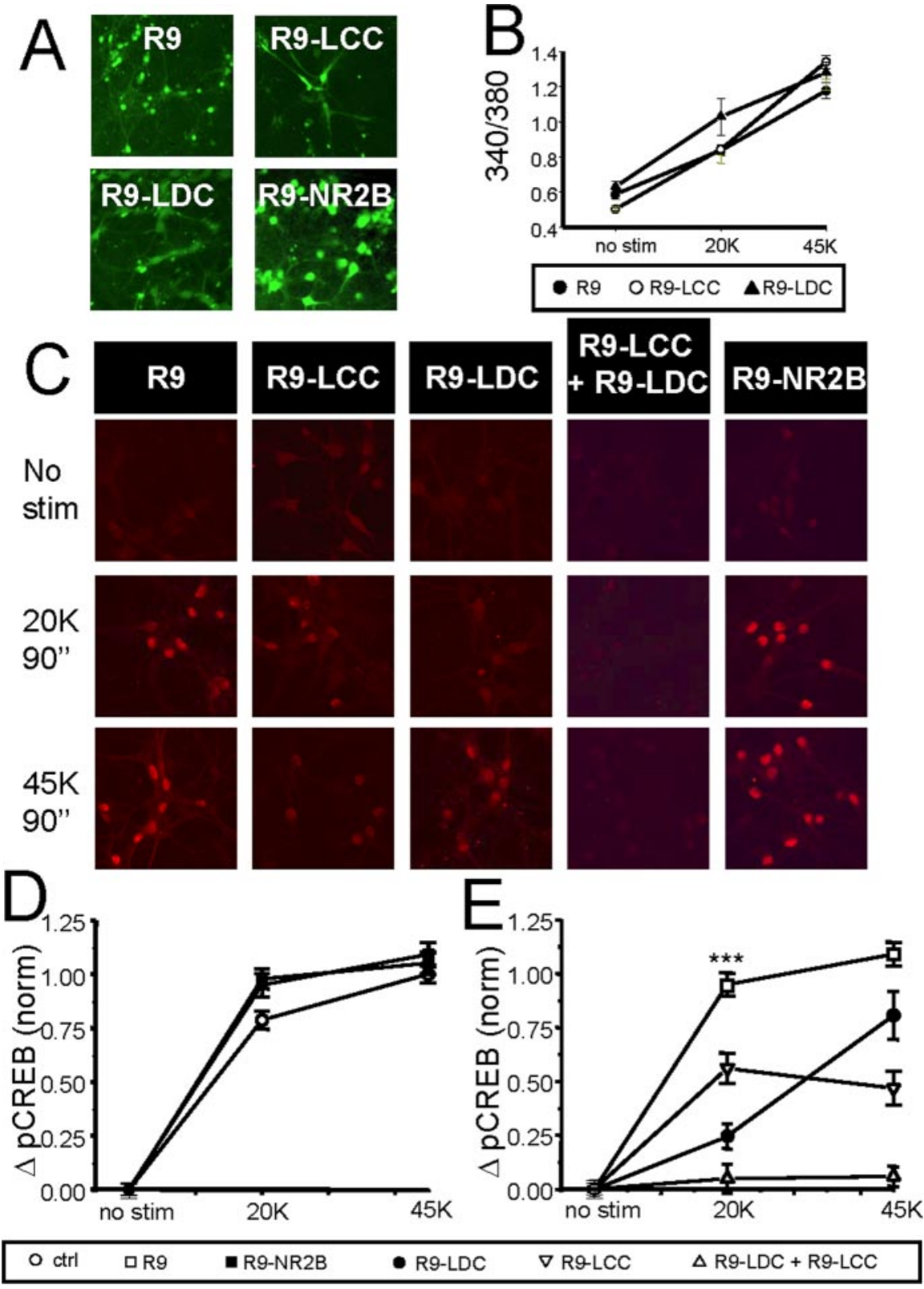

Figure 11. Effects of R9 competitive peptides on L-type $\mathrm{Ca}^{2+}$ channels mediated pCREB signaling. A, Loading of FITCconjugated R9, R9-LCC, R9-LDC, and R9-NR2B peptides into mature hippocampal neurons was visualized by FITC fluorescence. $B$, Hippocampal neurons loaded with R9, R9-LCC, and R9-LDC peptides were stimulated $3 \mathrm{~h}$ after loading for $60 \mathrm{~s}$ by $20 \mathrm{~mm} \mathrm{KCI}(20 \mathrm{~K})$ or $45 \mathrm{~mm} \mathrm{KCl} \mathrm{(45} \mathrm{K)} \mathrm{in} \mathrm{the} \mathrm{presence} \mathrm{of} 1 \mu \mathrm{m} \mathrm{TTX,} 50 \mu \mathrm{m} \mathrm{D}-\mathrm{AP}-5$, and $10 \mu \mathrm{m} \mathrm{CNQX.} \mathrm{An} \mathrm{average} \mathrm{peak} \mathrm{340/380} \mathrm{fura-2} \mathrm{ratio} \mathrm{is} \mathrm{shown}$ as a function of stimulus intensity for neurons loaded with R9 (filled circles; $n=18$ ), R9-LCC (open circles; $n \geq 17$ ), and R9-LDC (filled triangles; $n \geq 15$ ). C, The hippocampal neurons loaded with R9, R9-LCC, R9-LDC, R9-LDC plus R9-LCC, and R9-NR2B peptides were stimulated $3 \mathrm{~h}$ after loading for $90 \mathrm{~s}$ by $20 \mathrm{~mm} \mathrm{KCl} \mathrm{(20} \mathrm{K)} \mathrm{or} 45 \mathrm{~mm} \mathrm{KCl} \mathrm{(45} \mathrm{K)} \mathrm{in} \mathrm{the} \mathrm{presence} \mathrm{of} 1 \mu \mathrm{m} \mathrm{TTX,} 50 \mu \mathrm{m}$ D-AP-5, and $10 \mu \mathrm{M}$ CNQX and fixed and stained with anti-pCREB pAb. Confocal images of pCREB staining in stimulated and unstimulated neurons (no stim) are shown. $D, E$, An average stimulation-induced increase in normalized $p C R E B$ nuclear staining $(\triangle \mathrm{p} C R E B)$ is shown as a function of stimulus intensity for control neurons (open circles; $n \geq 70$ ), for neurons loaded with $R 9$ (open squares; $n \geq 118$ ), R9-NR2B (filled squares; $n \geq 55$ ), R9-LCC (open downward triangles; $n \geq 87$ ), R9-LDC (filled circles; $n \geq 72$ ), and R9-LCC plus R9-LDC mixture (open upward triangles; $n \geq 78$ ). At 20K stimulation, the increase in pCREB staining in R9-loaded neurons is significantly higher $\left({ }^{* * *} p<0.05\right)$ than in R9-LCC or R9-LDC-loaded neurons. At 45K stimulation, the increase in pCREB staining in R9-loaded neurons is significantly higher than in R9-LCC-loaded neurons but not in R9-LDC-loaded neurons.

the $\mathrm{C}$ termini of both $\mathrm{Ca}_{\mathrm{V}} 2.2$ and $\mathrm{Ca}_{\mathrm{V}} 1.3$ subunits contain proline-rich (PXXP) region, which in the case of $\mathrm{Ca}_{\mathrm{V}} 2.2$ binds to CASK-SH3 (Maximov et al., 1999) and in the case of $\mathrm{Ca}_{\mathrm{V}} 1.3$ binds to Shank-SH3 (Fig. $2 D, F$ ). Interestingly, Mint1 and CASK bind to each other (Butz et al., 1998) and therefore, $\mathrm{Ca}_{\mathrm{V}} 2.2 \mathrm{C}$ terminal binds to Mint1/CASK complex, whereas the $\mathrm{Ca}_{\mathrm{V}} 1.3 \mathrm{C}$ terminal binds to adjacent $\mathrm{PDZ}$ and $\mathrm{SH} 3$ domains of Shank. Both $\mathrm{Ca}_{\mathrm{V}} 2.2$ and $\mathrm{Ca}_{\mathrm{V}} 1.3$ subunits are alternatively spliced at their $\mathrm{C}$ termini, resulting in long $\left(\mathrm{Ca}_{\mathrm{V}} 2.2 \mathrm{a}\right.$ and $\left.\mathrm{Ca}_{\mathrm{V}} 1.3 \mathrm{a}\right)$ and short $\left(\mathrm{Ca}_{\mathrm{V}} 2.2 \mathrm{~b}\right.$ and $\left.\mathrm{Ca}_{\mathrm{V}} 1.3 \mathrm{~b}\right)$ isoforms (Williams et al., 1992; Safa et al., 2001; Xu and Lipscombe, 2001). Long, but not short, isoforms of $\mathrm{Ca}_{\mathrm{V}} 2.2$ and $\mathrm{Ca}_{\mathrm{V}} 1.3$ subunits contain PDZ and $\mathrm{SH} 3$ domainbinding motifs (Maximov et al., 1999) (Fig. $5 A$ ). In targeting experiments with HA$\mathrm{Ca}_{\mathrm{V}} 2.2$ and $\mathrm{HA}-\mathrm{Ca}_{\mathrm{V}} 1.3$ subunits, we found that long $\left(\mathrm{Ca}_{\mathrm{V}} 2.2 \mathrm{a}\right.$ and $\left.\mathrm{Ca}_{\mathrm{V}} 1.3 \mathrm{a}\right)$, but not short $\left(\mathrm{Ca}_{\mathrm{V}} 2.2 \mathrm{~b}\right.$ and $\left.\mathrm{Ca}_{\mathrm{V}} 1.3 \mathrm{~b}\right)$, isoforms formed synaptic clusters when expressed in hippocampal neurons (Maximov and Bezprozvanny, 2002) (Figs. 6-8). In previous experiments, we demonstrated that the presence of either Mint-PDZ1 and CASK-SH3 binding motifs is sufficient to support synaptic clustering of $\mathrm{HA}-\mathrm{Ca}_{\mathrm{V}} 2.2$ in hippocampal neurons (Maximov and Bezprozvanny, 2002). Now, we found that the presence of both Shank-PDZ and Shank-SH3 domainbinding motifs is necessary for synaptic clustering of HA-Ca 1.3 in hippocampal neurons (Figs. 4, 6-8).

Interactions with modular adaptor proteins and L-type $\mathrm{Ca}^{2+}$ channels signaling to $\mathrm{pCREB}$

Our data indicate that association of $\mathrm{Ca}_{\mathrm{V}} 1.3 \mathrm{~L}$-type $\mathrm{Ca}^{2+}$ channels with Shank is important for pCREB signaling. At low levels of $\mathrm{KCl}$ stimulation (20K for 90 s, $20 \mathrm{~K}$ or $45 \mathrm{~K}$ for $30 \mathrm{~s}$ ) and at $5 \mathrm{~Hz}$ EFS, truncated $\mathrm{Ca}_{\mathrm{V}} 1.3 \mathrm{a}-\Delta \mathrm{C}$ construct was significantly less potent in supporting pCREB signaling than the full-length $\mathrm{Ca}_{\mathrm{V}} 1.3$ construct (Fig. 10) (data not shown), although both constructs expressed in HEK293 cells and in Xenopus oocytes at similar levels (Figs. $5 C-E, 9 B, C)$ and supported similar $\mathrm{Ca}^{2+}$ influx in hippocampal neurons (Fig. 9D). Consistent with these findings, pCREB signaling was significantly suppressed in neurons loaded with R9-LDC peptide at low intensity of stimulation (20K for $90 \mathrm{~s}$ ) (Fig. $11 C, E$ ) without affecting total $\mathrm{Ca}^{2+}$ influx (Fig. $11 \mathrm{~B}$ ). In contrast to results obtained at low levels of stimulation, $\mathrm{Ca}_{\mathrm{V}} 1.3 \mathrm{a}-\Delta \mathrm{C}$ and $\mathrm{Ca}_{\mathrm{V}} 1.3$ constructs displayed a similar ability to support pCREB signaling at high levels of $\mathrm{KCl}$ stimulation ( $45 \mathrm{~K}$ or $90 \mathrm{~K}$ for $90 \mathrm{~s}, 90 \mathrm{~K}$ for $30 \mathrm{~s}$ ) (Fig. 10) (data not shown). Also, pCREB signaling was not significantly affected in the presence of R9-LDC peptide at 45K 90 s stimulation (Fig. 11C,E). These results are consistent with the idea that association of $\mathrm{Ca}_{\mathrm{V}} 1.3 \mathrm{a} \mathrm{L}$-type $\mathrm{Ca}^{2+}$ channels with Shank plays an important role in pCREB signaling at low levels of stimulation. At high-stimulation intensity, compartmentalization is lost, presumably because of larger $\mathrm{Ca}^{2+}$ flux via $\mathrm{Ca}_{\mathrm{V}} 1.3 \mathrm{~L}$-type channels. 
It is interesting to compare our findings regarding pCREB signaling supported by $\mathrm{Ca}_{\mathrm{V}} 1.3 \mathrm{~L}$-type $\mathrm{Ca}^{2+}$ channels with the recent analysis of pCREB signaling supported by $\mathrm{Ca}_{\mathrm{V}} 1.2 \mathrm{~L}$-type $\mathrm{Ca}^{2+}$ channels (Weick et al., 2003). Similar to our findings with $\mathrm{Ca}_{\mathrm{V}} 1.3$, deletion of PDZ domain-binding motif attenuated $\mathrm{Ca}_{\mathrm{V}} 1.2$-mediated pCREB signaling at low intensities of stimulation (20K for $3 \mathrm{~min}$ ) (Weick et al., 2003). In the same report, it was demonstrated that expression of EGFP-VSNL dominant-negative construct attenuated pCREB signaling at low $(20 \mathrm{~K}$ for $3 \mathrm{~min}$ ) and high ( $90 \mathrm{~K}$ for $3 \mathrm{~min}$ ) stimulation intensities (Weick et al., 2003). In agreement with these findings, loading of hippocampal neurons with R9-LCC peptide suppressed pCREB signaling in our experiments (Fig. $11 C, E$ ) without affecting total $\mathrm{Ca}^{2+}$ influx in the same stimulation conditions (Fig. $11 \mathrm{~B}$ ). Thus, for both L-type $\mathrm{Ca}^{2+}$ channel isoforms, association with PDZ domain proteins (NIL-16 for $\mathrm{Ca}_{\mathrm{V}} 1.2$ and Shank for $\mathrm{Ca}_{\mathrm{V}} 1.3 \mathrm{a}$ ) plays an important role in mediating efficient signaling to pCREB in hippocampal neurons. Consistent with this conclusion, simultaneous delivery of R9-LCC and R9-LDC competitive peptides uncoupled $\mathrm{KCl}$ depolarization from L-type $\mathrm{Ca}^{2+}$ channelmediated pCREB responses (Fig. 11C,E). When compared with $\mathrm{Ca}_{\mathrm{V}} 1.2 \mathrm{~L}$-type $\mathrm{Ca}^{2+}$ channels, $\mathrm{Ca}_{\mathrm{V}} 1.3 \mathrm{~L}$-type $\mathrm{Ca}^{2+}$ channels open at more negative membrane potentials (Koschak et al., 2001; Xu and Lipscombe, 2001; Lipscombe et al., 2004; Olson et al., 2005) and therefore $\mathrm{Ca}_{\mathrm{V}} 1.3 \mathrm{~L}$-type $\mathrm{Ca}^{2+}$ channels are more likely to play a predominant role in PCREB signaling at low levels of depolarization, when $\mathrm{Ca}_{\mathrm{V}} 1.3$ association with Shank is of particular importance.

\section{$\mathrm{Ca}_{\mathrm{V}}$ 1.3 L-type $\mathrm{Ca}^{2+}$ channels and macromolecular postsynaptic $\mathrm{Ca}^{2+}$ signaling complex}

In conclusion, here, we show that the long splice variant of neuronal L-type $\mathrm{Ca}^{2+}$ channels pore-forming subunit $\mathrm{Ca}_{\mathrm{V}} 1.3 \mathrm{a}$ is specifically associated with Shank postsynaptic modular adaptor protein. $\mathrm{Ca}_{\mathrm{V}}$ 1.3a-Shank association is mediated via $\mathrm{PDZ}$ and $\mathrm{SH} 3$ domains of Shank and C-terminal region of $\mathrm{Ca}_{\mathrm{V}} 1.3 \mathrm{a}$ (Figs. 1, 2). Shank proteins (Fig. $1 \mathrm{~B}$ ) have been proposed to play a role of master scaffold in the postsynaptic specialization (Sheng and Kim, 2000). Via proline-rich region, Shank proteins bind to adaptor protein Homer ( $\mathrm{Tu}$ et al., 1999), which in turn binds to InsP $_{3} \mathrm{R} 1$ and mGluR1 $\alpha / 5$ (Tu et al., 1998). Via PDZ domain, Shank is associated with GKAP-PSD95-NR2B (Boeckers et al., 1999; Naisbitt et al., 1999; Tu et al., 1999; Yao et al., 1999). SAM and PDZ domains allow Shank to multimerize (Sheng and Kim, 2000; Im et al., 2003), which may lead to formation of extended polymeric structures in postsynaptic specialization. Interactions listed above bring together a number of channels and signaling molecules involved in the control of intracellular $\mathrm{Ca}^{2+}$ concentration in postsynaptic spines of glutamatergic synapses (Kennedy, 2000). Our results indicate the following: (1) $\mathrm{Ca}_{\mathrm{V}} 1.3 \mathrm{a}$ L-type channels and Shank colocalize in postsynaptic locations in hippocampal neurons (Figs. 3, 7, 8); (2) Shank-binding motif in $\mathrm{Ca}_{\mathrm{V}} 1.3 \mathrm{a}$ sequence plays a critical role in synaptic clustering of L-type $\mathrm{Ca}^{2+}$ channels in hippocampal neurons (Figs. 4, 6-8); and (3) Shank-binding motif in $\mathrm{Ca}_{\mathrm{V}} 1$.3a sequence is necessary for an efficient signaling from $\mathrm{Ca}_{\mathrm{V}} 1.3 \mathrm{~L}$-type $\mathrm{Ca}^{2+}$ channels to pCREB in hippocampal neurons (Figs. 10,11). Thus, results in our study demonstrate that $\mathrm{Ca}_{\mathrm{V}} 1.3 \mathrm{~L}$-type $\mathrm{Ca}^{2+}$ channels is a part of macromolecular $\mathrm{Ca}^{2+}$ signaling complex organized by Shank in postsynaptic spines in hippocampal neurons. This conclusion is consistent with the emerging role of L-type voltage-gated $\mathrm{Ca}^{2+}$ channels in $\mathrm{Ca}^{2+}$ signaling in hippocampal postsynaptic spines (Sabatini and Svoboda, 2000; Hoogland and Saggau, 2004). In the accompanying study (Olson et al., 2005), we further examine an importance of $\mathrm{Ca}_{\mathrm{V}} 1.3$-Shank association for $\mathrm{Ca}^{2+}$ signaling mediated by $\mathrm{L}$-type $\mathrm{Ca}^{2+}$ channels in medium spiny striatal neurons.

\section{References}

Bezprozvanny I, Maximov A (2001) Classification of PDZ domains. FEBS Lett 509:457-462.

Bezprozvanny I, Tsien RW (1995) Voltage-dependent blockage of diverse types of voltage-gated $\mathrm{Ca}^{2+}$ channels expressed in Xenopus oocytes by the $\mathrm{Ca}^{2+}$ channel antagonist mibefradil (Ro 40-5967). Mol Pharmacol 48:540-549.

Bito H, Deisseroth K, Tsien RW (1996) CREB phosphorylation and dephosphorylation: a $\mathrm{Ca}^{2+}$ - and stimulus duration-dependent switch for hippocampal gene expression. Cell 87:1203-1214.

Boeckers TM, Winter C, Smalla KH, Kreutz MR, Bockmann J, Seidenbecher C, Garner CC, Gundelfinger ED (1999) Proline-rich synapse-associated proteins ProSAP1 and ProSAP2 interact with synaptic proteins of the SAPAP/GKAP family. Biochem Biophys Res Commun 264:247-252.

Butz S, Okamoto M, Sudhof TC (1998) A tripartite protein complex with the potential to couple synaptic vesicle exocytosis to cell adhesion in brain. Cell 94:773-782.

Catterall WA (2000) Structure and regulation of voltage-gated $\mathrm{Ca}^{2+}$ channels. Annu Rev Cell Dev Biol 16:521-555.

Deisseroth K, Mermelstein PG, Xia H, Tsien RW (2003) Signaling from synapse to nucleus: the logic behind the mechanisms. Curr Opin Neurobiol 13:354-365.

Dolmetsch RE, Pajvani U, Fife K, Spotts JM, Greenberg ME (2001) Signaling to the nucleus by an L-type calcium channel-calmodulin complex through the MAP kinase pathway. Science 294:333-339.

Dunlap K, Luebke JI, Turner TJ (1995) Exocytotic $\mathrm{Ca}^{2+}$ channels in mammalian central neurons. Trends Neurosci 18:89-98.

Graef IA, Mermelstein PG, Stankunas K, Neilson JR, Deisseroth K, Tsien RW, Crabtree GR (1999) L-type calcium channels and GSK-3 regulate the activity of NF-ATc4 in hippocampal neurons. Nature 401:703-708.

He M, Bodi I, Mikala G, Schwartz A (1997) Motif III S5 of L-type calcium channels is involved in the dihydropyridine binding site. A combined radioligand binding and electrophysiological study. J Biol Chem 272:2629-2633.

Hell JW, Westenbroek RE, Warner C, Ahlijanian MK, Prystay W, Gilbert MM, Snutch TP, Catterall WA (1993) Identification and differential subcellular localization of the neuronal class C and class D L-type calcium channel alpha 1 subunits. J Cell Biol 123:949-962.

Hibino H, Pironkova R, Onwumere O, Vologodskaia M, Hudspeth AJ, Lesage F (2002) RIM binding proteins (RBPs) couple Rab3-interacting molecules (RIMs) to voltage-gated $\mathrm{Ca}^{2+}$ channels. Neuron 34:411-423.

Hoogland TM, Saggau P (2004) Facilitation of L-type $\mathrm{Ca}^{2+}$ channels in dendritic spines by activation of $\beta 2$ adrenergic receptors. J Neurosci 24:8416-8427.

Ihara Y, Yamada Y, Fujii Y, Gonoi T, Yano H, Yasuda K, Inagaki N, Seino Y, Seino S (1995) Molecular diversity and functional characterization of voltage-dependent calcium channels (CACN4) expressed in pancreatic beta-cells. Mol Endocrinol 9:121-130.

Im YJ, Lee JH, Park SH, Park SJ, Rho SH, Kang GB, Kim E, Eom SH (2003) Crystal structure of the Shank PDZ-ligand complex reveals a class I PDZ interaction and a novel PDZ-PDZ dimerization. J Biol Chem 278:48099-48104.

Kennedy MB (2000) Signal-processing machines at the postsynaptic density. Science 290:750-754.

Koschak A, Reimer D, Huber I, Grabner M, Glossmann H, Engel J, Striessnig J (2001) $\alpha 1 \mathrm{D}(\mathrm{Cav1.3})$ subunits can form l-type $\mathrm{Ca}^{2+}$ channels activating at negative voltages. J Biol Chem 276:22100-22106.

Kurschner C, Yuzaki M (1999) Neuronal interleukin-16 (NIL-16): a dual function PDZ domain protein. J Neurosci 19:7770-7780.

Kurschner C, Mermelstein PG, Holden WT, Surmeier DJ (1998) CIPP, a novel multivalent PDZ domain protein, selectively interacts with Kir4.0 family members, NMDA receptor subunits, neurexins, and neuroligins. Mol Cell Neurosci 11:161-172.

Lim S, Naisbitt S, Yoon J, Hwang JI, Suh PG, Sheng M, Kim E (1999) Characterization of the Shank family of synaptic proteins. Multiple genes, alternative splicing, and differential expression in brain and development. J Biol Chem 274:29510-29518. 
Lipscombe D, Helton TD, Xu W (2004) L-type calcium channels: the low down. J Neurophysiol 92:2633-2641.

Liu G, Dilmac N, Hilliard N, Hockerman GH (2003) Cav1.3 is preferentially coupled to glucose-stimulated insulin secretion in the pancreatic beta-cell line INS-1. J Pharmacol Exp Ther 305:271-278.

Mangoni ME, Couette B, Bourinet E, Platzer J, Reimer D, Striessnig J, Nargeot J (2003) Functional role of L-type Cav1.3 $\mathrm{Ca}^{2+}$ channels in cardiac pacemaker activity. Proc Natl Acad Sci USA 100:5543-5548.

Maximov A, Bezprozvanny I (2002) Synaptic targeting of N-type calcium channels in hippocampal neurons. J Neurosci 22:6939-6952.

Maximov A, Sudhof TC, Bezprozvanny I (1999) Association of neuronal calcium channels with modular adaptor proteins. J Biol Chem 274:24453-24456.

Mikami A, Imoto K, Tanabe T, Niidome T, Mori Y, Takeshima H, Narumiya S, Numa S (1989) Primary structure and functional expression of the cardiac dihydropyridine-sensitive calcium channel. Nature 340:230-233.

Naisbitt S, Kim E, Tu JC, Xiao B, Sala C, Valtschanoff J, Weinberg RJ, Worley PF, Sheng M (1999) Shank, a novel family of postsynaptic density proteins that binds to the NMDA receptor/PSD-95/GKAP complex and cortactin. Neuron 23:569-582.

Namkung Y, Skrypnyk N, Jeong MJ, Lee T, Lee MS, Kim HL, Chin H, Suh PG, Kim SS, Shin HS (2001) Requirement for the L-type $\mathrm{Ca}^{2+}$ channel alpha(1D) subunit in postnatal pancreatic beta cell generation. J Clin Invest 108:1015-1022.

Olson PA, Tkatch T, Hernandez-Lopez S, Ulrich S, Ilijic E, Mugnaini E, Zhang H, Bezprozvanny I, Surmeier DJ (2005) G-protein-coupled receptor modulation of striatal $\mathrm{Ca}_{\mathrm{V}} 1.3 \mathrm{~L}$-type $\mathrm{Ca}^{2+}$ channels is dependent on a Shank-binding domain. J Neurosci 25:1050-1062.

Platzer J, Engel J, Schrott-Fischer A, Stephan K, Bova S, Chen H, Zheng H, Striessnig J (2000) Congenital deafness and sinoatrial node dysfunction in mice lacking class D L-type $\mathrm{Ca}^{2+}$ channels. Cell 102:89-97.

Sabatini BL, Svoboda K (2000) Analysis of calcium channels in single spines using optical fluctuation analysis. Nature 408:589-593.

Safa P, Boulter J, Hales TG (2001) Functional properties of Cav1.3 (alpha1D) L-type $\mathrm{Ca}^{2+}$ channel splice variants expressed by rat brain and neuroendocrine GH3 cells. J Biol Chem 276:38727-38737.

Sala C, Futai K, Yamamoto K, Worley PF, Hayashi Y, Sheng M (2003) Inhibition of dendritic spine morphogenesis and synaptic transmission by activity-inducible protein Homerla. J Neurosci 23:6327-6337.

Schwarze SR, Hruska KA, Dowdy SF (2000) Protein transduction: unrestricted delivery into all cells? Trends Cell Biol 10:290-295.
Sheng M, Kim E (2000) The Shank family of scaffold proteins. J Cell Sci 113:1851-1856.

Songyang Z, Fanning AS, Fu C, Xu J, Marfatia SM, Chishti AH, Crompton A, Chan AC, Anderson JM, Cantley LC (1997) Recognition of unique carboxyl-terminal motifs by distinct PDZ domains. Science 275:73-77.

Tang TS, Bezprozvanny I (2004) Dopamine receptor-mediated $\mathrm{Ca}^{2+}$ signaling in striatal medium spiny neurons. J Biol Chem 279:42082-42094.

Tang T-S, Tu H, Chan EY, Maximov A, Wang Z, Wellington CL, Hayden MR, Bezprozvanny I (2003) Huntingtin and huntingtin-associated protein 1 influence neuronal calcium signaling mediated by inositol- $(1,4,5)$ triphosphate receptor type 1. Neuron 39:227-239.

Tu JC, Xiao B, Yuan JP, Lanahan AA, Leoffert K, Li M, Linden DJ, Worley PF (1998) Homer binds a novel proline-rich motif and links group 1 metabotropic glutamate receptors with $\mathrm{IP}_{3}$ receptors. Neuron 21:717-726.

Tu JC, Xiao B, Naisbitt S, Yuan JP, Petralia RS, Brakeman P, Doan A, Aakalu VK, Lanahan AA, Sheng M, Worley PF (1999) Coupling of mGluR/ Homer and PSD-95 complexes by the Shank family of postsynaptic density proteins. Neuron 23:583-592.

Weick JP, Groth RD, Isaksen AL, Mermelstein PG (2003) Interactions with PDZ proteins are required for L-type calcium channels to activate cAMP response element-binding protein-dependent gene expression. J Neurosci 23:3446-3456.

Wender PA, Mitchell DJ, Pattabiraman K, Pelkey ET, Steinman L, Rothbard JB (2000) The design, synthesis, and evaluation of molecules that enable or enhance cellular uptake: peptoid molecular transporters. Proc Natl Acad Sci USA 97:13003-13008.

Williams ME, Brust PF, Feldman DH, Patthi S, Simerson S, Maroufi A, McCue AF, Velicelebi G, Ellis SB, Harpold MM (1992) Structure and functional expression of an omega-conotoxin-sensitive human N-type calcium channel. Science 257:389-395.

Xu W, Lipscombe D (2001) Neuronal Ca(V)1.3 $\alpha(1)$ L-type channels activate at relatively hyperpolarized membrane potentials and are incompletely inhibited by dihydropyridines. J Neurosci 21:5944-5951.

Yao I, Hata Y, Hirao K, Deguchi M, Ide N, Takeuchi M, Takai Y (1999) Synamon, a novel neuronal protein interacting with synapse-associated protein 90/postsynaptic density-95-associated protein. J Biol Chem 274:27463-27466.

Zhang Z, Xu Y, Song H, Rodriguez J, Tuteja D, Namkung Y, Shin HS, Chiamvimonvat N (2002) Functional roles of $\mathrm{Ca}(\mathrm{v}) 1.3$ (alpha(1D)) calcium channel in sinoatrial nodes: insight gained using gene-targeted null mutant mice. Circ Res 90:981-987. 